\title{
Is educational wellbeing associated with grade repetition and school dropout rates among Indian students? Evidence from a panel study
}

\author{
Ronak Paul ${ }^{1}$ and Rashmi ${ }^{1, *}$
}

\begin{abstract}
Despite the Indian government's continuing efforts to encourage children to attend school, levels of educational wellbeing among some groups of children during their elementary schooling remain low. High school dropout and grade repetition rates are among the negative and deleterious outcomes of poor educational wellbeing in children that are rarely discussed as policy issues. Using the panel dataset of the India Human Development Survey (IHDS) conducted in 2005 and 2012, this study explores the effects of educational wellbeing on children's later educational outcomes, as measured by their school dropout and grade repetition rates. Variation in the educational outcomes of children across states was also examined. The results show that the children whose educational wellbeing index was below average during their elementary schooling were more likely to drop out of school or repeat a grade in early adolescence. For policymakers, this study highlights that the experiences of children during their elementary schooling merit more attention.
\end{abstract}

Keywords: educational wellbeing; school dropout; grade repetition; educational outcome; India Human Development Survey

\section{Introduction}

Education is a complex process that involves a combination of individual ability and motivation, as well as resources provided by the family, and actions taken by communities and states (Darling-Hammond et al. 2020). Thus, education can be seen as a lifelong process that ends with death, and that improves the lives of

\footnotetext{
${ }^{1}$ International Institute for Population Sciences, Mumbai, India

${ }^{*}$ Correspondence to: Rashmi, rashmir635@gmail.com
} 
individuals, while supporting the progress of nations. Globally, various programs have been proposed that seek to improve the lives of all people based on a commitment to "Education for All". Despite being a developing country, India has implemented educational initiatives within the framework of the country's Global Goals, including a universal elementary education program in 1992, the Sarva Shiksha Abhiyan program, the Right to Education Act, and a mid-day meal scheme (Govinda and Bandyopadhyay 2008). While the achievements of these initiatives, including improvements in access to education, have been reported in the previous literature, the goal of the universalisation of education has yet to be realised in India (Chudgar 2009; Gouda and Sekher 2014).

A recent report on the National Education Policy (NEP) of India found that the government's commitment to ensuring that all children attend school starting at early ages is likely to be achieved in the near future, as the gross enrolment ratio among children in grades 6-8 recently reached $91 \%$ (MHRD 2020). However, the same report showed that the gross enrolment ratio was $79 \%$ among children in grades $9-10$, and was $56 \%$ among children in grades 11-12, which indicates that many children leave education during adolescence. Moreover, while the Annual Status of Education Report (ASER) 2018 found that 97\% of Indian children had enrolled in school, it also showed that half of these children were unable to read grade 2-level textbooks at ages $10-11$, and only $28 \%$ of students were able to divide appropriately in grade 5. Against this background, we seek to answer the question of how the educational wellbeing of children during their elementary schooling contributes to their likelihood of dropping out of school or repeating a grade during adolescence.

Wellbeing is defined as a state in which the physical, cognitive and socialemotional dimensions of an individual are well-integrated (Bornstein et al. 2003). It is a complex concept that includes both objective and subjective measures related to the individual's circumstances. An Indian study published in 2019 listed 13 different domains of wellbeing, among which education was identified as a potential driver of the wellbeing of individuals (Singh et al. 2019). Different approaches to measuring wellbeing may include the use of both objective and subjective criteria that are designed to reflect the quality of life, experiences and needs of the population (see Table 1). Educational wellbeing in children is usually assessed by measuring children's school performance, learning skills, cognitive development, involvement in education and enjoyment of education (Sylva 1994; Wat 2015). When children fail to learn and to perform well in their early years of schooling, they often develop a negative attitude towards education, which may, in turn, further disrupt their education during adolescence. Thus, a lack of educational wellbeing may be associated with higher school dropout and grade repetition rates. A child is considered a school dropout if he or she fails to complete the basic cycle of schooling (Sabates et al. 2010). Grade repetition is the practice of having a child attend the same grade for another year because she or he was unable to fulfil a pre-set academic goal (Haidary 2013). 
Table 1:

\section{List of indicators of educational wellbeing and reasons for inclusion}

\begin{tabular}{lll}
\hline S. No. & \multicolumn{1}{c}{ Indicators } & \multicolumn{1}{c}{ Reason for inclusion } \\
\hline $\begin{array}{l}\text { 1. Objective } \\
\text { educational } \\
\text { wellbeing } \\
\text { index }\end{array}$ & $\begin{array}{c}\text { Reading skills, } \\
\text { mathematical skills, } \\
\text { writing skills }\end{array}$ & $\begin{array}{c}\text { Rather than focusing on the self-reported } \\
\text { educational attainment of children, it is more } \\
\text { useful to evaluate the extent to which students } \\
\text { can use their reading, mathematical and writing } \\
\text { skills in real-life situations. These skills are } \\
\text { cognitive abilities that students must develop in } \\
\text { order to use the information mentioned or } \\
\text { implied (OECD 2003). }\end{array}$ \\
$\begin{array}{l}\text { Wellbeing includes both subjective and objective } \\
\text { 2. Subjective } \\
\text { educational } \\
\text { wellbeing } \\
\text { index }\end{array}$ & $\begin{array}{l}\text { Type of student, } \\
\text { student enjoys school }\end{array}$ & $\begin{array}{l}\text { aspects of life. These subjective educational } \\
\text { wellbeing indicators can be used to measure } \\
\text { aspects of children's school performance that } \\
\text { are directly or indirectly related to their } \\
\text { educational attainment (Sylva 1994). }\end{array}$ \\
& &
\end{tabular}

Source: Author's elaboration.

There is, however, little previous research on the role educational wellbeing plays in the likelihood that a child will drop out of school or experience repetitive failures (Falch and Strøm 2008; Glick and Sahn 2010). Most of the existing studies on this topic for India focused on identifying the determinants of high school dropout and grade repetition rates, including poverty (Rao 2000), the gender of the children (Upendranath 1995), the educational status of the parents (Pratinidhi et al. 1992), school facilities (Gouda et al. 2013), private tuition (Dongre and Tewary 2015), whether the schools are public or private (Desai et al. 2008b; Singhal and Das 2019), parental aspirations (Sethi 2018), family size (Choudhury 2006), religion and household characteristics (Bhat and Zavier 2005; Gouda and Sekher 2014). Moreover, it has been shown that the educational outcomes of children vary across the different regions and states of India (Gouda and Sekher 2014).

In addition to the lack of research on the determinants high school dropout and grade repetition rates, only a few studies have investigated how grade repetition affects the stress levels of early adolescents (Jimerson 2001; McGrath 2006); or the long-term effects of educational failures on levels of poverty, child labour, illiteracy, unemployment, low wages, participation in violence and crime, and mental and physical health problems (Beauvais et al. 1996; Desai 1991; UNESCO 2012). While these consequences are well-known, there is a lack of research in the Indian context on the association between educational wellbeing and grade repetition and dropout rates. To help fill this knowledge gap, the present study explores how the educational wellbeing of children affects their later educational development, as reflected in their 
school dropout and grade repetition rates. The panel dataset of the India Human Development Survey (IHDS) conducted in 2005 and 2012 further strengthens our study, as it measured the contribution of the educational wellbeing of children at ages 8-11 in round one, and again in early adolescence (at ages 15-18) in round two. Our study also takes into account the variation across states in detrimental educational outcomes - namely, dropping out of school and repeating a grade while examining the hypothesised association.

\section{Data, variables and methods}

\subsection{Data source}

This study uses data from round one and round two of the India Human Development Survey (IHDS), which provide information on the health and morbidity, education, employment, economic status, nuptiality, fertility, gender relations and social capital of a nationally representative sample of 41,554 households. Round one of the IHDS was conducted in 2005-2006. In round two of the IHDS, which was carried out in 2011-2012, 83\% of the households surveyed in round one were re-interviewed. Unlike other cross-sectional surveys conducted in India, such as the National Family Health Survey (NFHS), the IHDS covered a wide range of topics, and had a panel design. The National Council of Applied Economic Research (NCAER) conducted both rounds of the IHDS in collaboration with the University of Maryland, USA. The IHDS had a multistage, stratified, random sampling survey design, and covered all of the states and the union territories of India. Further details regarding the IHDS' sample frame, sampling procedures and data collection approaches can be found elsewhere (Desai et al. 2010, 2015).

Our study utilises the panel data for 9840 students who were $8-11$ years old in 2005 (round one), and who were 15-18 years old in 2012 (round two). Of the 17,061 children who participated in round one (cross-sectional dataset), 104 had died, 3454 had migrated and 3663 were untraceable during round two. Furthermore, we have excluded the data for 18 children for whom the information regarding their school dropout and grade repetition status was missing in round two. Thus, the analytical sample we use to investigate the relationship between educational wellbeing in round one and school dropout and grade retention status in round two consists of 9822 students.

\subsection{Ethics statement}

The analysis presented in this article is based on publicly available secondary data with no identifiable information. Therefore, no prior ethical approval for our study was necessary. The data can be obtained from the Inter-university Consortium for 
Political and Social Research (ICPSR) data repository (Desai and Vanneman 2015; Desai et al. 2008a).

\subsection{Outcome variables}

The indicators of the school dropout status (no, yes) and the grade repetition status (no, yes) of the students in our analytical sample between 2005 and 2012 are the two outcome variables of our study. The school dropout status of the students was obtained from the binary indicators of their school enrolment status in 2005 and 2012 , respectively. Children who were enrolled in school during round one, but who were not enrolled during round two, were categorised as "yes" (school dropout), and were otherwise categorised as "no". Similarly, the grade repetition status of students was obtained from the responses to the following item collected in both rounds: "has the student ever repeated a grade - yes, no". Students who had never repeated a grade in 2005, but who had repeated at least one grade in 2012, were categorised as "yes", and were otherwise categorised as "no".

\subsection{Key explanatory variable}

The two binary indicators of educational wellbeing are the key independent variables of our study. While wellbeing cannot be measured directly, it can be estimated using closely related subjective and objective measures. To measure the educational wellbeing of students, we created two educational wellbeing indices (the objective educational wellbeing index and the subjective educational wellbeing index) from five educational outcome indicators. These educational outcome indicators were provided only for students aged 8-11 in round one of the IHDS (Desai et al. 2010). Two of these indicators were reported by the child's mother, and are subjective measures of educational wellbeing: namely, what type of student the child is (below average, average, above average), and whether the child enjoys school (no, yes). The other three indicators are objective measures of educational wellbeing: namely, the child's reading, mathematical and writing skills. These measures were developed from short reading, mathematical and writing tests administered to all students aged 8-11 in the households the IHDS surveyed. The reading skills of students are divided into five categories: (i) cannot read at all, (ii) can read alphabets but not words, (iii) can read words but cannot read full sentences, (iv) can read a short paragraph of 2-3 sentences but cannot read a full page and (v) can read a full story. The mathematical skills of students are divided into four categories: (i) cannot read numbers, (ii) can recognise numbers but cannot do any arithmetic operations, (iii) can subtract a two-digit number from another number and (iv) can divide a threedigit number by a one-digit number. The writing skills of students are divided into two categories: (i) cannot write at all and (ii) can write a sentence with two or fewer mistakes. Distribution of students by these variables are presented in Table A.1 and the technical details of the construction of the index are provided in Section 2.6.1. 


\subsection{Control variables}

Previous research has shown that several factors influence the school dropout and grade repetition rates of students (Falch and Strøm 2008; Glick and Sahn 2010; Gouda and Sekher 2014). Accordingly, we have included relevant student-related characteristics, parent-related characteristics and socio-economic characteristics of the household as control variables. The student-related characteristics are as follows: the age of the student (in completed years), the gender of the student (male, female), the type of school the student attends (public school, private school, other) and whether the student receives private tuition (no, yes). The parent-related control variables are as follows: mother's level of education (no formal schooling, less than five years of schooling, six to 10 years of schooling, more than 10 years of schooling), mother's working status (not working, working), father's level of education (no formal schooling, less than five years of schooling, six to 10 years of schooling, more than 10 years of schooling) and father's working status (not working, working). The control variables related to the household's socio-economic characteristics are as follows: household wealth quintile (richest, rich, middle, poor and poorest), household poverty status (not poor, poor), the caste of the household head (Other Backward Class (OBC), Scheduled Castes (SC), Scheduled Tribes (ST), other), the religion of the household head (Hindu, Muslim, other) and the place of residence (rural, urban). Additionally, the region of the country (northern, northeastern, central, eastern, western, southern) the student came from is included as a state-level characteristic. All of these variables are measured for the panel of children aged $8-11$ in 2005.

We have estimated the wealth quintile for all households in round one using data on each household's asset ownership, material type, water source, sanitation facility type and number of bedrooms. This approach is based on globally-defined standard procedures (Filmer and Scott 2008; Rutstein and Johnson 2004). The wealth scores for each household have been generated using principal component analysis (Filmer and Scott 2008). Based on the wealth score, the households have been classified into five categories (richest, rich, middle, poor, poorest), such that the households with the lowest 20th percentile score are assigned to the "poorest" category; the households with the next-lowest 20th percentile score are assigned to the "poor" category; and so on.

During round one, information was collected about the religion and caste of all household heads. Based on their religion, the households have been assigned to nine categories: Hindu, Muslim, Christian, Sikh, Buddhist, Jain, tribal, other and none. Owing to the skewed population distribution, for the purposes of this study, we have recoded the religion of the household head into three categories: Hindu, Muslim and other, whereby the other category consists of all other religious categories except Hindu and Muslim. Similarly, the IHDS classified the caste of the household head into five categories: Brahmin, Other Backward Caste [OBC], Scheduled Caste [SC], Scheduled Tribe $[\mathrm{ST}]$ and other. Again, we have recoded the caste variable into four categories: OBC, SC, ST and other, whereby the other category combines the 
Brahmin and the other categories from the original variable. The respondents in the ST and the SC categories belong to the most socially backward group of people; i.e., they are members of the lower rungs of the now constitutionally abolished Indian caste system. As the name suggests, the respondents in the OBC category also belong to a socially and economically backward group of people, although they tend to have better conditions than those of the SC/ST people. The other category consists of all respondents who do not belong to any of the three caste groups.

We constructed the country regions by assigning the current and erstwhile 33 states and union territories of India to six categories. The northern region includes Chandigarh, Delhi, Haryana Himachal Pradesh, erstwhile Jammu and Kashmir, Punjab, Uttaranchal and Rajasthan. The north-eastern region includes Assam, Arunachal Pradesh, Manipur, Meghalaya, Mizoram, Nagaland, Tripura and Sikkim. The central region consists of Madhya Pradesh and Chhattisgarh. The eastern zone consists of Bihar, Jharkhand, Odisha and West Bengal. The western region comprises Dadra and Nagar Haveli, Daman and Diu, Goa, Gujarat and Maharashtra. The southern region comprises erstwhile Andhra Pradesh, Karnataka, Kerala, Tamil Nadu and Pondicherry (Sanjay 2020).

\subsection{Statistical methods}

\subsubsection{Construction of the objective and the subjective educational wellbeing index}

The educational wellbeing index was constructed using principal component factor analysis (PCFA) based on the variables described in Section 2.4. PCFA is a dimension reduction method that is utilised to reduce the information provided by a large group of variables (indicators of educational wellbeing) to form a smaller group (educational wellbeing index) that contains the majority of the information from the larger group (Fabrigar et al. 1999). The use of a composite index, rather than numerous indicators, has the added advantage of being easier to interpret and to compute (Costello and Osborne 2005). The PCFA method transforms a large number of correlated variables into a smaller number of uncorrelated factors. The first principal factor accounts for as much of the variability in the data as possible, with each succeeding factor then accounting for as much of the remaining variability as possible (Costello and Osborne 2005). The relevance of each factor can be determined from the eigenvalue, which indicates how much of the total variance is explained by each of the factors (Acock 2013). Any factor with an eigenvalue of less than or equal to one is ignored. The factor loadings are the correlation between each variable and the factor we are interested in (Acock 2013). Factor loading values of greater than 0.25 indicate that the variable is relevant in defining the dimensionality of the factor, with higher values denoting increasing relevance (Acock 2013). A negative factor loading value indicates an inverse correlation with the factor. 
Table 2:

Factor loading and inter-item correlation obtained from the principal component factor analysis (PCFA)

\begin{tabular}{lccc}
\hline Scale & Items & Factor Loading & KMO Value \\
\hline Objective educational wellbeing index & & & \\
$\quad$ Eigen value $=2.38$ & Reading skills & 0.88 & 0.70 \\
$\quad$ Explained variance $=47.5 \%$ & Mathematical skills & 0.88 & 0.72 \\
& Writing skills & 0.84 & 0.80 \\
Subjective educational wellbeing index & & & \\
$\quad$ Eigen value $=1.29$ & Type of student & 0.60 & 0.84 \\
Explained variance $=25.8 \%$ & Student enjoys school & 0.89 & 0.74 \\
\hline
\end{tabular}

Note: (a) Kaiser-Meier-Olkin measure indicates whether there is sufficient correlation among the indicator variables to perform PCFA.

Source: Author's calculation using IHDS data (2005).

The PCFA for the indicators of educational wellbeing result in a two-factor solution. Looking at Table 2, we can observe that both factor 1 and factor 2 have an eigenvalue greater than one, with each factor explaining $48 \%$ and $26 \%$ of the variance of all of the indicators of educational wellbeing, respectively. Furthermore, all of the indicators have factor loading values of more than 0.60 . In addition, all of the indicators have Kaiser-Meier-Olkin (KMO) values greater than 0.70, which justifies our use of PCFA (KMO values greater than 0.50 are necessary for conducting PCFA).

In addition, we have generated objective and subjective educational wellbeing scores based on the first and second factors, respectively. The objective and subjective scores have mean values of zero and median values of 0.38 and 0.14 , respectively, thereby denoting a negatively skewed distribution. Thus, we have obtained two binary indexes of objective educational wellbeing and subjective educational wellbeing in which students have a score that is below the median value (below-average score), or a score that is higher than or equal to the median value (average and above score).

As we noted above, we have chosen to use PCFA over other methods of index construction that are based on the reliability coefficient only (Muttarak and Chankrajang 2015). While measures based on reliability coefficients give equal weights to all components of the index, this approach is rarely applicable in practical scenarios (Kline 2000). The advantage of using PCA is that it weights each component proportional to its correlation with the concept that we are trying to measure with the index. Therefore, an index constructed through PCA has been shown to better represent the concept in terms of measurement validity (Acock 2013; Costello and Osborne 2005). 


\subsubsection{Bivariate and multivariate analysis}

We use bivariate and multivariable analysis to explore the effects of children's educational wellbeing on their later educational outcomes, as measured by their school dropout and grade repetition rates. Bivariate analysis is carried out using the chi-square test for association. The outcome variables, school dropout and grade repetition status are binary. As further sampling units in the survey have been chosen using a stratified random sampling approach, observations within the same strata will have a certain level of correlation among them. Thus, to account for the type of the dependent variable and the stratified nature of the data, we have estimated two-level random intercept logistic regression models. In the two-level model, 9822 students are included in level 1, and these students are nested within 21 states in level 2. Note that because of the skewed distribution of students across the 33 states (in the study sample), we have merged them into 21 groups, such that the union territories, the states in the north-eastern region, and Maharashtra and Goa are in singular groups. The grouping of union territories is based on the similarity of the administrative structure, whereas the grouping of the north-eastern states and Maharashtra and Goa is based on geographical proximity. In addition, although the students are nested within households, which are, in turn, nested within states in the data, we do not include the household as a separate level, as the average number of students per household (1.2) is very low (Steele 2013).

The multivariable model gives an odds ratio, which is the odds of a person being in a particular category in comparison to the reference category after adjusting for the effects of all other variables, and for the group-level effects (Steele 2013). In addition, the multilevel model gives the intraclass correlation coefficient (ICC), which measures the expected degree of similarity (homogeneity) of the school dropout (or grade repetition) rate among students in the same state. The ICC at the state level is the ratio of unexplained variation in the risk of dropping out of school (or of repeating a grade) across the states to the sum of the total unexplained variation. The value of the ICC lies within zero and one, such that the higher the value of the ICC, the greater the degree of within-state correlation is (Merlo et al. 2006). The median odds ratio (MOR) measures the expected degree of heterogeneity of the school dropout (or grade repetition) rate among students in the different states. The MOR at the state level gives the median of the ratio of the likelihood of dropping out of school (or of repeating a grade) among all pairs of students belonging to highrisk and low-risk states. The value of the MOR is always greater than or equal to one, such that a higher MOR value denotes a greater level of heterogeneity (Merlo et al. 2006).

We checked for multicollinearity and found that the mean-variance inflation factor (VIF) for all multivariable models was less than 1.28 (Ender 2010). Therefore, multicollinearity does not affect our multivariate estimations. We performed all statistical estimations using the Stata software version 13 (StataCorp 2014). 


\section{Results}

\subsection{Sample description}

Of the children in our study sample, nearly $57 \%$ had average and above objective educational wellbeing scores, and 50\% had average and above subjective educational wellbeing scores in 2005. Looking at Table 3, we can see that of the panel of children, $53 \%$ were male and $47 \%$ were female. Moreover, $70 \%$ of the students were attending public school, and 82\% were not receiving private tuition in 2005 . Turning to parental education, we can see that $55 \%$ of the students had a mother and $26 \%$ had a father with no formal schooling. In terms of household economic status, $38 \%$ of the students came from a household in the poor/poorest wealth quintile, and $29 \%$ came from a household below the poverty line (BPL). Moreover, $40 \%$ of the students were from OBC households, 79\% were from Hindu families and $72 \%$ were from rural households. In terms of region of the country, the vast majority of students came from the northern region (38\%), distantly followed by the southern regions $(18 \%)$.

The last column of Table 3 gives the absolute difference in the percentage distribution of students across the cross-sectional and panel populations in 2005. Note that the percentage distribution of students across the characteristics is largely similar in the two datasets, which indicates that the study is unlikely to suffer from a sample selection bias, whereby students with certain selected characteristics had a greater likelihood of dropping out of the survey in the second wave. Only the percentage distribution by the father's education differed by more than $5 \%$ between the two datasets.

\subsection{Bivariate results}

Table 4 displays the bivariate association between the educational wellbeing of students and other control variables in round one with the dropout and grade repetition status of students in round two. We found that among the 9822 students, $2273(23 \%)$ had dropped out of school and $1668(17 \%)$ had repeated a grade between 2005-2012. The bivariate results showed that students with a belowaverage objective wellbeing score in 2005 were highly likely to have dropped out of school $(31 \%)$ or repeated a grade $(20 \%)$ by 2012 . Similarly, among the students who had a below-average subjective educational wellbeing score, the proportions who dropped out of school (27\%) or repeated a grade (18\%) were relatively large. Furthermore, larger shares of public school than of private school students had dropped out $(28 \%)$ or repeated a grade $(20 \%)$ by 2012 . Moreover, among the students whose mother had no formal schooling, the shares who dropped out of school $(32 \%)$ or repeated a grade (19\%) were disproportionately large. Likewise, among the students whose father had no formal schooling, the shares who dropped out of school $(36 \%)$ or repeated a grade $(19 \%)$ were relatively large. 
Table 3:

Absolute (N) and percentage (\%) distribution of students aged 8-11 years by relevant demographic and socio-economic characteristics across the cross-sectional and panel datasets in round one

\begin{tabular}{|c|c|c|c|c|c|}
\hline \multirow[b]{3}{*}{ Characteristics } & \multicolumn{4}{|c|}{ Students aged 8-11 years in 2005} & \multirow{3}{*}{$\begin{array}{c}\text { Absolute } \\
\text { difference } \\
\%\end{array}$} \\
\hline & \multicolumn{2}{|c|}{$\begin{array}{c}\text { Cross-sectional } \\
\text { dataset }\end{array}$} & \multicolumn{2}{|c|}{$\begin{array}{c}\text { Panel } \\
\text { dataset }\end{array}$} & \\
\hline & $N$ & $\%$ & $N$ & $\%$ & \\
\hline \multicolumn{6}{|l|}{ Age of student (in years) } \\
\hline 8 & 4,311 & 25.3 & 2,131 & 21.7 & 3.6 \\
\hline 9 & 3,714 & 21.8 & 2,315 & 23.6 & 1.8 \\
\hline 10 & 5,596 & 32.8 & 3,552 & 36.2 & 3.4 \\
\hline 11 & 3,440 & 20.2 & 1,824 & 18.6 & 1.6 \\
\hline \multicolumn{6}{|l|}{ Gender of student } \\
\hline Male & 8,940 & 52.4 & 5,243 & 53.4 & 1.0 \\
\hline Female & 8,121 & 47.6 & 4,579 & 46.6 & 1.0 \\
\hline \multicolumn{6}{|l|}{ Type of school attended by student } \\
\hline Public school & 10,308 & 66.6 & 6,846 & 69.7 & 3.1 \\
\hline Private school & 4,167 & 26.9 & 2,417 & 24.6 & 2.3 \\
\hline Others & 991 & 6.4 & 559 & 5.7 & 0.7 \\
\hline \multicolumn{6}{|l|}{ Student receives private tuition } \\
\hline No & 9,941 & 77.6 & 8,117 & 82.6 & 5.0 \\
\hline Yes & 2,863 & 22.4 & 1,705 & 17.4 & 5.0 \\
\hline \multicolumn{6}{|l|}{ Mother's level of education } \\
\hline More than 10 years of schooling & 1,081 & 6.6 & 596 & 6.1 & 0.5 \\
\hline 6 to 10 years of schooling & 3,717 & 22.8 & 2,176 & 22.2 & 0.6 \\
\hline Less than 5 years of schooling & 2,595 & 15.9 & 1,628 & 16.6 & 0.7 \\
\hline No formal schooling & 8,943 & 54.7 & 5,422 & 55.2 & 0.5 \\
\hline \multicolumn{6}{|l|}{ Mother's working status } \\
\hline Not working & 12,040 & 73.3 & 7,303 & 74.4 & 1.1 \\
\hline Working & 4,377 & 26.7 & 2,519 & 25.6 & 1.1 \\
\hline \multicolumn{6}{|l|}{ Father's level of education } \\
\hline More than 10 years of schooling & 2,357 & 15.3 & 1,297 & 13.2 & 2.1 \\
\hline 6 to 10 years of schooling & 5,495 & 35.6 & 4,220 & 43.0 & 7.4 \\
\hline Less than 5 years of schooling & 2,913 & 18.9 & 1,732 & 17.6 & 1.3 \\
\hline No formal schooling & 4,654 & 30.2 & 2,573 & 26.2 & 4.0 \\
\hline \multicolumn{6}{|l|}{ Father's working status } \\
\hline Not working & 5,189 & 33.5 & 3,114 & 31.7 & 1.8 \\
\hline Working & 10,287 & 66.5 & 6,708 & 68.3 & 1.8 \\
\hline
\end{tabular}

Continued 
Table 3:

Continued

\begin{tabular}{|c|c|c|c|c|c|}
\hline \multirow[b]{3}{*}{ Characteristics } & \multicolumn{4}{|c|}{ Students aged 8-11 years in 2005} & \multirow{3}{*}{$\begin{array}{c}\text { Absolute } \\
\text { difference } \\
\%\end{array}$} \\
\hline & \multicolumn{2}{|c|}{$\begin{array}{c}\text { Cross-sectional } \\
\text { dataset }\end{array}$} & \multicolumn{2}{|c|}{$\begin{array}{c}\text { Panel } \\
\text { dataset }\end{array}$} & \\
\hline & $N$ & $\%$ & $N$ & $\%$ & \\
\hline \multicolumn{6}{|l|}{ Household wealth quintile } \\
\hline Richest & 3,285 & 19.3 & 1,909 & 19.4 & 0.1 \\
\hline Rich & 3,593 & 21.1 & 2,099 & 21.4 & 0.3 \\
\hline Middle & 3,437 & 20.1 & 2,077 & 21.1 & 1.0 \\
\hline Poor & 3,404 & 20.0 & 1,932 & 19.7 & 0.3 \\
\hline Poorest & 3,342 & 19.6 & 1,805 & 18.4 & 1.2 \\
\hline \multicolumn{6}{|l|}{ Household poverty status } \\
\hline Not poor & 12,146 & 71.2 & 7,003 & 71.3 & 0.1 \\
\hline Poor & 4,915 & 28.8 & 2,819 & 28.7 & 0.1 \\
\hline \multicolumn{6}{|l|}{ Caste of household head } \\
\hline Scheduled Tribes & 1,333 & 7.8 & 702 & 7.1 & 0.7 \\
\hline Scheduled Castes & 3,729 & 21.9 & 2,242 & 22.8 & 0.9 \\
\hline Other Backward Classes & 6,889 & 40.4 & 3,928 & 40.0 & 0.4 \\
\hline Others & 5,110 & 30.0 & 2,950 & 30.0 & 0.0 \\
\hline \multicolumn{6}{|l|}{ Religion of household head } \\
\hline Hindu & 13,353 & 78.3 & 7,781 & 79.2 & 0.9 \\
\hline Muslim & 2,532 & 14.8 & 1,349 & 13.7 & 1.1 \\
\hline Others & 1,176 & 6.9 & 692 & 7.0 & 0.1 \\
\hline \multicolumn{6}{|l|}{ Place of residence } \\
\hline Rural & 12,040 & 70.6 & 7,034 & 71.6 & 1.0 \\
\hline Urban & 5,021 & 29.4 & 2,788 & 28.4 & 1.0 \\
\hline \multicolumn{6}{|l|}{ Country regions } \\
\hline Northern & 6,339 & 37.2 & 3,767 & 38.4 & 1.2 \\
\hline North-eastern & 615 & 3.6 & 260 & 2.6 & 1.0 \\
\hline Central & 1,888 & 11.1 & 1,096 & 11.2 & 0.1 \\
\hline Eastern & 2,845 & 16.7 & 1,530 & 15.6 & 1.1 \\
\hline Western & 2,210 & 13.0 & 1,437 & 14.6 & 1.6 \\
\hline Southern & 3,164 & 18.5 & 1,732 & 17.6 & 0.9 \\
\hline Overall & 17,061 & 100 & $\mathbf{9 , 8 2 2}$ & 100 & \\
\hline
\end{tabular}

Source: Author's calculation using IHDS data (2005).

When we looked at the role of socio-economic characteristics, we found that the shares of students who dropped out were especially large among those who came from a household that was in the poor wealth quintile $(39 \%)$ or below the poverty line $(35 \%)$. We observed a similar pattern for grade repetition, whereby $23 \%$ of students from a household in the poor wealth quintile and $22 \%$ of students from 


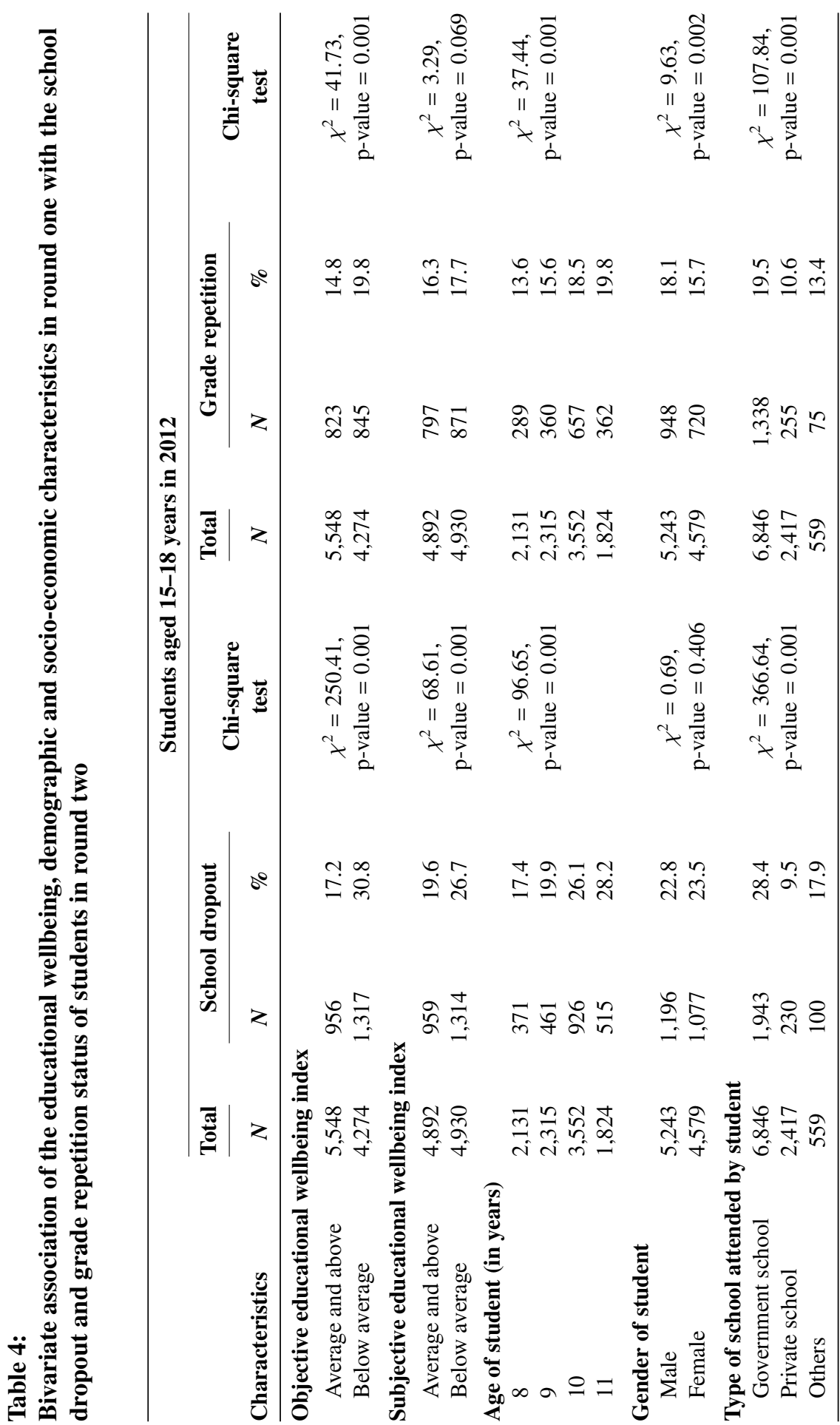




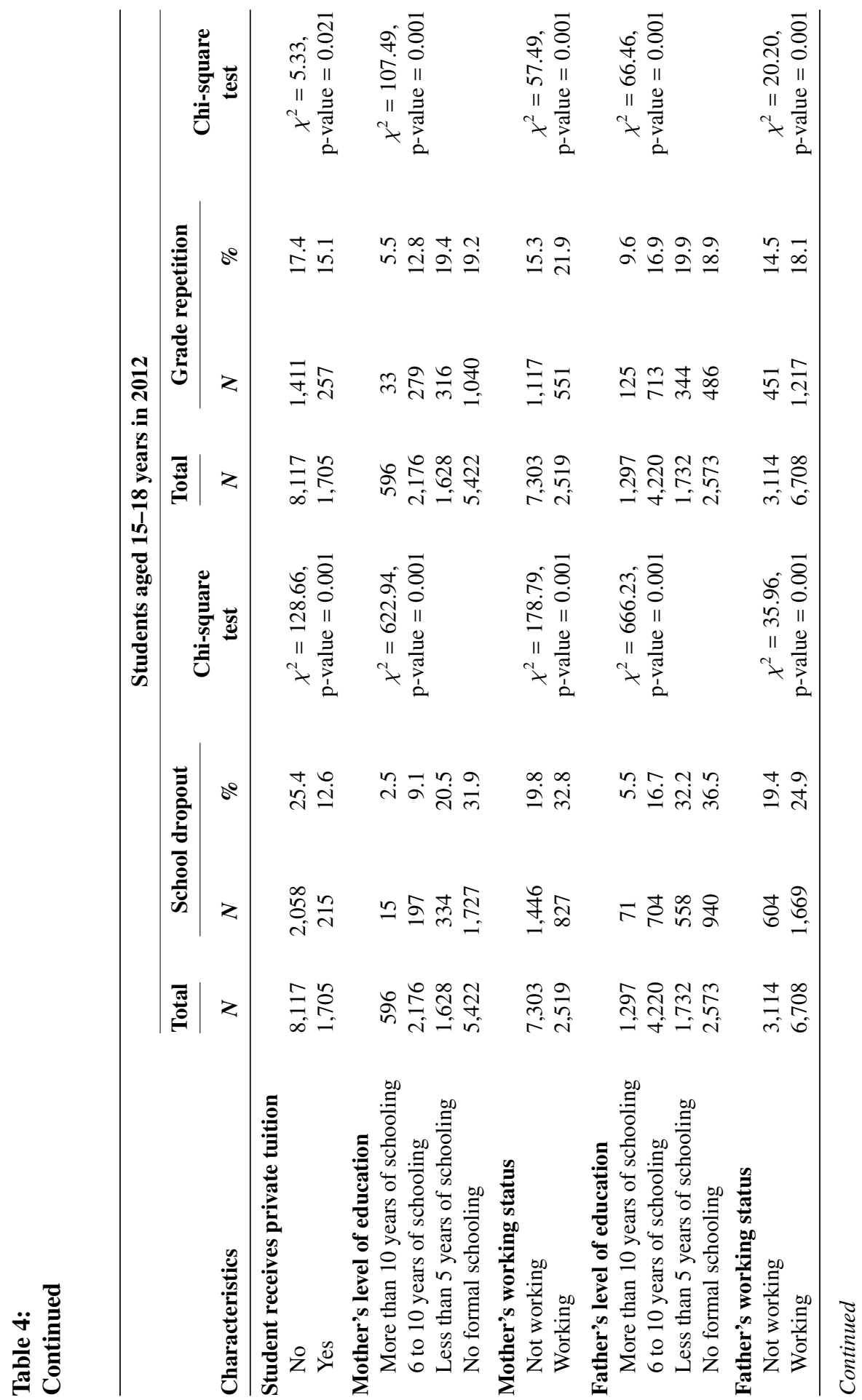




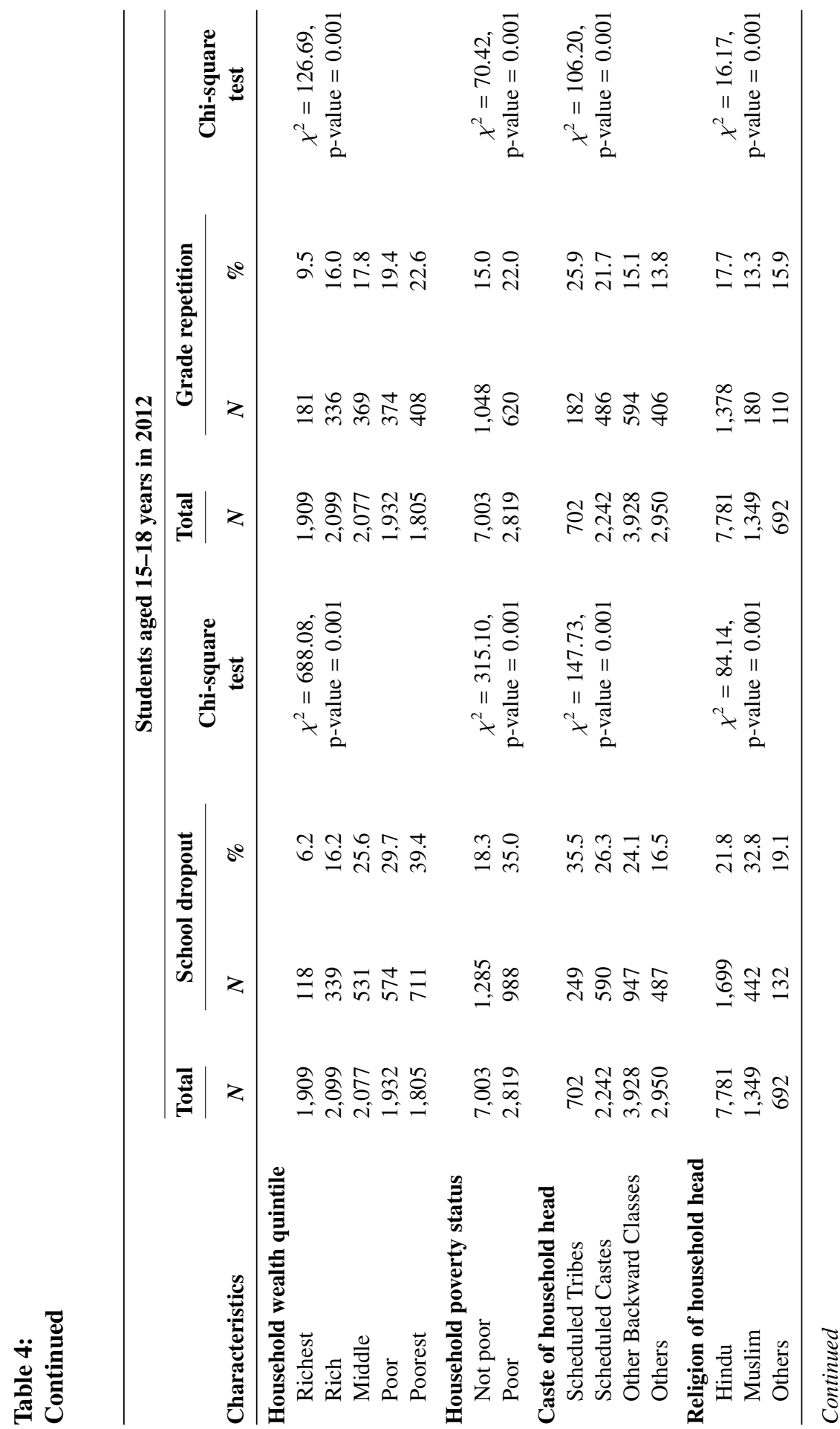




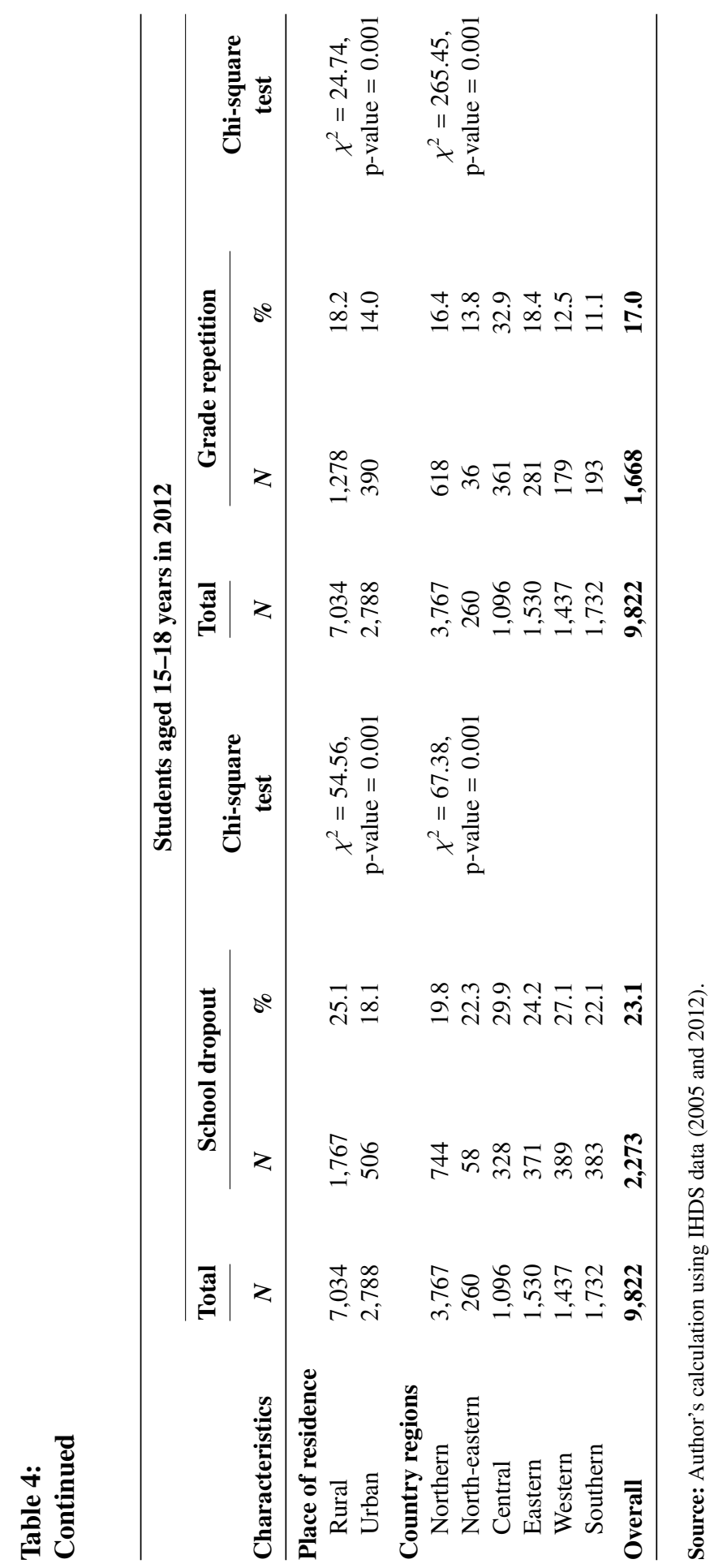


a BPL household had repeated a grade. We further observed that $36 \%$ of students who belonged to the Scheduled Tribes and $25 \%$ of students from a rural community had dropped out of school by 2012. Similarly, 26\% of ST students and 18\% of rural students had repeated a grade by 2012 . Moreover, we found that the shares of students who dropped out of school $(30 \%)$ or repeated a grade $(33 \%)$ were relatively large in the central region of India.

\subsection{Multivariable results}

Table 5 provides the parameters of the group-level (state-level) effects from the random intercept logit models for the school dropout and grade repetition rates, respectively. The ICC from the null models showed that the state-level characteristics accounted for $11 \%$ and $8 \%$ of the unexplained variation among the students in the risk of dropping out of school or of repeating a grade in 2012, respectively. The MOR showed that among students from high-risk states, the risk of dropping out of school was 1.84 times higher, and the risk of repeating a grade was 1.68 times higher in 2012. From the null to the full models, both the ICC and the MOR declined due to the inclusion of explanatory covariates, which reduced the unexplained variance at the state level (Steele 2013).

After adjusting for the effects of the independent variables and the state-level effects, Table 6 shows the associations between the students' educational wellbeing

\section{Table 5:}

State-level effects from the random intercept logistic regression models during round two

\begin{tabular}{|c|c|c|c|c|}
\hline \multirow[b]{3}{*}{ Random effect parameters } & \multicolumn{4}{|c|}{ Students aged 15-18 years in 2012} \\
\hline & \multicolumn{2}{|c|}{ School dropout } & \multicolumn{2}{|c|}{ Grade repetition } \\
\hline & $\begin{array}{c}\text { Null } \\
\text { Model }\end{array}$ & $\begin{array}{c}\text { Full } \\
\text { Model }\end{array}$ & $\begin{array}{c}\text { Null } \\
\text { Model }\end{array}$ & $\begin{array}{c}\text { Full } \\
\text { Mode }\end{array}$ \\
\hline \multicolumn{5}{|l|}{ Level 2: States of India } \\
\hline Variance & 0.406 & 0.246 & 0.293 & 0.162 \\
\hline Intraclass correlation coefficient (ICC in \%) & 10.99 & 6.95 & 8.19 & 4.69 \\
\hline Median odds ratio (MOR) & 1.84 & 1.60 & 1.68 & 1.47 \\
\hline Likelihood ratio test significance & $* * *$ & $* * *$ & $* * *$ & $* * *$ \\
\hline Number of states & 21 & 21 & 21 & 21 \\
\hline Number of students & 9822 & 9822 & 9822 & 9822 \\
\hline
\end{tabular}

Note: (a) The null model is an empty model without any explanatory and control variables. (b) The full model contains all the explanatory and control variables. (c) The school dropout and grade repetition variable is categorised into no, yes. (d) The likelihood ratio test shows the significance of using a multilevel logistic model over a standard logistic model where ${ }^{* * *}$ denotes p-value $<0.001$.

Source: Author's calculation using IHDS data (2012). 
Table 6:

Odds ratios from the random-intercept logistic regression models showing the association of the educational wellbeing and demographic and socio-economic characteristics of students in round one with the school dropout and grade repetition status of students in round two

\begin{tabular}{|c|c|c|c|c|}
\hline \multirow[t]{3}{*}{ Characteristics } & \multicolumn{4}{|c|}{ Students aged $15-18$ years in 2012} \\
\hline & \multicolumn{2}{|c|}{ School dropout } & \multicolumn{2}{|c|}{ Grade repetition } \\
\hline & OR & $95 \%$ CI & OR & $95 \%$ CI \\
\hline $\begin{array}{l}\text { Objective educational wellbein } \\
\text { Average and above }{ }^{\circledR} \\
\text { Below average }\end{array}$ & $1.65^{*}$ & $(1.48-1.85)$ & $1.33^{*}$ & $(1.18-1.49)$ \\
\hline $\begin{array}{l}\text { Subjective educational wellbeir } \\
\text { Average and above }{ }^{\circledR} \\
\text { Below average }\end{array}$ & $1.30^{*}$ & $(1.16-1.45)$ & $1.17^{*}$ & $(1.04-1.31)$ \\
\hline $\begin{array}{l}\text { Age of student (in years) } \\
8^{\circledR} \\
9 \\
10 \\
11\end{array}$ & $\begin{array}{l}1.43^{*} \\
2.07^{*} \\
2.72^{*}\end{array}$ & $\begin{array}{l}(1.21-1.69) \\
(1.79-2.40) \\
(2.30-3.23)\end{array}$ & $\begin{array}{l}1.24^{*} \\
1.57^{*} \\
1.82^{*}\end{array}$ & $\begin{array}{l}(1.04-1.48) \\
(1.34-1.83) \\
(1.53-2.18)\end{array}$ \\
\hline $\begin{array}{l}\text { Gender of student } \\
\text { Male }^{\circledR} \\
\text { Female }\end{array}$ & 1.07 & $(0.96-1.19)$ & $0.82^{*}$ & $(0.74-0.92)$ \\
\hline $\begin{array}{l}\text { Type of school attended by stuc } \\
\text { Private school }{ }^{\circledR} \\
\text { Public school } \\
\text { Others }\end{array}$ & $\begin{array}{l}1.75^{*} \\
1.64^{*}\end{array}$ & $\begin{array}{l}(1.47-2.08) \\
(1.23-2.20)\end{array}$ & $\begin{array}{l}1.42^{*} \\
1.43^{*}\end{array}$ & $\begin{array}{l}(1.20-1.68) \\
(1.07-1.92)\end{array}$ \\
\hline $\begin{array}{l}\text { Student receives private tuition } \\
\text { Yes }{ }^{\circledR} \\
\text { No }\end{array}$ & $1.41^{*}$ & $(1.17-1.69)$ & 0.96 & $(0.81-1.13)$ \\
\hline $\begin{array}{l}\text { Mother's level of education } \\
\text { More than } 10 \text { years of schooli } \\
6 \text { to } 10 \text { years of schooling } \\
\text { Less than } 5 \text { years of schooling } \\
\text { No formal schooling }\end{array}$ & $\begin{array}{l}1.85^{*} \\
2.71^{*} \\
3.69^{*}\end{array}$ & $\begin{array}{l}(1.06-3.22) \\
(1.55-4.74) \\
(2.12-6.41)\end{array}$ & $\begin{array}{l}1.82^{*} \\
2.28^{*} \\
2.11^{*}\end{array}$ & $\begin{array}{l}(1.22-2.70) \\
(1.51-3.42) \\
(1.41-3.16)\end{array}$ \\
\hline $\begin{array}{l}\text { Mother's working status } \\
\text { Not working }{ }^{\circledR} \\
\text { Working }\end{array}$ & 1.11 & $(0.97-1.26)$ & $1.24^{*}$ & $(1.07-1.43)$ \\
\hline $\begin{array}{l}\text { Father's level of education } \\
\text { More than } 10 \text { years of schooling }\end{array}$ & & & & \\
\hline $\begin{array}{l}6 \text { to } 10 \text { years of schooling } \\
\text { Less than } 5 \text { years of schooling } \\
\text { No formal schooling }\end{array}$ & $\begin{array}{l}1.79 * \\
2.71 * \\
2.61 *\end{array}$ & $\begin{array}{l}(1.36-2.35) \\
(2.04-3.60) \\
(1.96-3.46)\end{array}$ & $\begin{array}{l}1.34 * \\
1.29 * \\
1.15\end{array}$ & $\begin{array}{l}(1.08-1.68) \\
(1.01-1.66) \\
(0.90-1.48)\end{array}$ \\
\hline
\end{tabular}


Table 6:

Continued

\begin{tabular}{|c|c|c|c|c|}
\hline \multirow[t]{3}{*}{ Characteristics } & \multicolumn{4}{|c|}{ Students aged 15-18 years in 2012} \\
\hline & \multicolumn{2}{|c|}{ School dropout } & \multicolumn{2}{|c|}{ Grade repetition } \\
\hline & OR & $95 \% \mathrm{CI}$ & OR & $95 \% \mathrm{CI}$ \\
\hline $\begin{array}{l}\text { Father's working status } \\
\text { Not working }{ }^{\circledR} \\
\text { Working }\end{array}$ & 0.98 & $(0.87-1.12)$ & 1.01 & $(0.89-1.16)$ \\
\hline $\begin{array}{l}\text { Household wealth quintile } \\
\text { Richest }{ }^{\circledR} \\
\text { Rich } \\
\text { Middle } \\
\text { Poor } \\
\text { Poorest }\end{array}$ & $\begin{array}{l}1.62^{*} \\
2.42^{*} \\
2.61^{*} \\
3.50^{*}\end{array}$ & $\begin{array}{l}(1.27-2.06) \\
(1.89-3.11) \\
(2.00-3.40) \\
(2.63-4.65)\end{array}$ & $\begin{array}{l}1.39^{*} \\
1.39^{*} \\
1.35^{*} \\
1.34^{*}\end{array}$ & $\begin{array}{l}(1.13-1.72) \\
(1.11-1.75) \\
(1.05-1.74) \\
(1.02-1.78)\end{array}$ \\
\hline $\begin{array}{l}\text { Household poverty status } \\
\text { Not poor }{ }^{\circledR} \\
\text { Poor }\end{array}$ & $1.27^{*}$ & $(1.12-1.43)$ & 1.09 & $(0.95-1.25)$ \\
\hline $\begin{array}{l}\text { Caste of household head } \\
\text { Scheduled Tribes }{ }^{\circledR} \\
\text { Scheduled Castes } \\
\text { Other Backward Classes } \\
\text { Others }\end{array}$ & $\begin{array}{l}1.06 \\
1.00 \\
0.92\end{array}$ & $\begin{array}{l}(0.86-1.31) \\
(0.81-1.22) \\
(0.73-1.15)\end{array}$ & $\begin{array}{l}1.04 \\
0.81 \\
0.77^{*}\end{array}$ & $\begin{array}{l}(0.83-1.29) \\
(0.65-1.01) \\
(0.61-0.98)\end{array}$ \\
\hline $\begin{array}{l}\text { Religion of household head } \\
\text { Hindu } \\
\text { Muslim } \\
\text { Others }\end{array}$ & $\begin{array}{l}2.13^{*} \\
0.97\end{array}$ & $\begin{array}{l}(1.81-2.51) \\
(0.74-1.26)\end{array}$ & $\begin{array}{l}0.80^{*} \\
1.03\end{array}$ & $\begin{array}{l}(0.66-0.98) \\
(0.79-1.35)\end{array}$ \\
\hline $\begin{array}{l}\text { Place of residence } \\
\text { Rural }{ }^{\circledR} \\
\text { Urban }\end{array}$ & $1.45^{*}$ & $(1.25-1.69)$ & 1.10 & $(0.94-1.28)$ \\
\hline $\begin{array}{l}\text { Country regions } \\
\text { Northern } \\
\text { North-eastern } \\
\text { Central } \\
\text { Eastern } \\
\text { Western } \\
\text { Southern }\end{array}$ & $\begin{array}{l}1.69 \\
1.33 \\
1.02 \\
2.90^{*} \\
1.01\end{array}$ & $\begin{array}{l}(0.57-5.03) \\
(0.60-2.96) \\
(0.55-1.91) \\
(1.51-5.59) \\
(0.56-1.84)\end{array}$ & $\begin{array}{l}0.66 \\
1.78 \\
0.64 \\
0.46^{*} \\
0.50^{*}\end{array}$ & $\begin{array}{l}(0.26-1.67) \\
(0.93-3.43) \\
(0.38-1.09) \\
(0.25-0.84) \\
(0.31-0.82)\end{array}$ \\
\hline $\begin{array}{l}\text { Number of states } \\
\text { Number of students }\end{array}$ & & & & \\
\hline
\end{tabular}

Note: (a) OR stands for the odds ratio. (b) The $95 \%$ confidence interval (CI) is given in brackets. (c) Statistical significance is denoted by asterisks, where $*$ denotes p-value $<0.05$. (d) ${ }^{\mathbb{R}}$ denotes the reference category. (e) The school dropout and grade repetition variable is categorised into no, yes.

Source: Author's calculation using IHDS data (2005 and 2012). 
and other control variables in 2005 and their school dropout and grade repetition status in 2012. The multivariate analysis indicated that compared to students with above-average wellbeing scores, students with below-average objective wellbeing scores in 2005 were 1.65 [CI: 1.48-1.85] times more likely to have dropped out of school and 1.33 [CI: 1.18-1.49] times more likely to have repeated a grade between 2005-2012. Similarly, the odds of dropping out of school [OR: 1.30, CI: 1.16-1.45] and of repeating a grade [OR: 1.17, CI: 1.04-1.31] were found to be higher among students with below-average subjective educational wellbeing scores. Additionally, we observed that compared to students who were attending a private school, students who were attending a public school in 2005 were 1.75 [CI: 1.47-2.08] times more likely to have dropped out of school and were 1.42 [CI: 1.20-1.68] times more likely to have repeated a grade. Moreover, we found that the likelihood of having dropped out of school was 3.69 [CI: 2.12-6.41] times higher among students whose mother had no formal schooling, and was 2.61 [CI: 1.96-3.46] times higher among students whose father had no formal schooling. Similarly, the odds of grade repetition were shown to be higher for students whose mother and father had no formal schooling. In addition, our results showed that compared to students from the richest quintile households, students from the poorest wealth quintile households were 3.50 [CI: 2.63-4.65] times more likely to have dropped out of school and 1.34 [CI: 1.021.78] times more likely to have repeated a grade. We also found that compared to students living in rural communities, students living in urban communities were 1.45 [CI: 1.25-1.69] times more likely to have dropped out of school.

Furthermore, we tested the interaction effects to explore whether the effects of the objective and the subjective wellbeing indices on the dropout and grade repetition status of students varied by the mother's level of education and by household wealth (see Tables A.3 and A.4 in the appendix section). The empirical evidence showed that the mother having higher education significantly reduced students' chances of dropping out of school and repeating a grade, particularly among girls (Cardoso and Verner 2006; Lloyd et al. 2009; Marphatia et al. 2019). A potential explanation for this finding is that the mother's education protects her children from having below-average educational wellbeing, and thus lowers their chances of experiencing unfavourable educational outcomes, like dropping out of school or repeating a grade. Moreover, previous evidence has shown that the traits of households in the poor wealth quintile may negatively influence the schooling outcomes of the students in these households (Marphatia et al. 2019; Paul et al. 2021; Pong and Ju 2000). Thus, it is clear that coming from a higher income household may pave the way for students to receive more educational resources, like higher quality schooling and tailored tuition. Such amenities can support the educational wellbeing of children, which can, in turn, further reduce their chances of dropping out of school or repeating a grade. Therefore, we examined the interaction effects of educational wellbeing with the mother's education and household wealth. However, we found that the interaction coefficients were not statistically significant (see Tables A.3 and A.4 in the appendix section), which indicates that the effects of the objective 
and the subjective wellbeing indices on the dropout and grade repetition status of students did not vary by either the mother's education or the household wealth.

\section{Discussion}

Using the IHDS panel dataset conducted in 2005 and 2012, we have explored the association between the educational wellbeing of children at ages 8-11 and their likelihood of dropping out or repeating a grade at ages 15-18. Our study provides evidence that Indian children whose objective and subjective educational wellbeing scores were below average during their elementary schooling were more likely to drop out or repeat a grade during their early adolescence. Estimates from our multilevel model indicated that the school dropout and grade retention rates among children varied across states. In addition, we found that while including covariates further decreased the measure of variance in the outcomes, higher unobserved heterogeneity in the school dropout and grade retention rates of children persisted at the state level.

Thus, the analysis clearly showed that the children in our study sample were at greater risk of dropping out or of repeating a grade if they had below-average scores on the educational wellbeing index (both objective and subjective), which included indicators such as measures of a child's school performance, learning skills, cognitive development, involvement in education and enjoyment of education. The results were consistent with the findings of previous scholars, who argued that children's prior academic performance often explains their probability of dropping out of upper secondary education (Falch and Strøm 2008). In line with our findings, previous research has shown that children who have poor school performance and lower learning and cognitive skill levels are at greater risk of failing a grade and of discontinuing their secondary schooling (Fetler 1989). It is worth noting that in the Indian context, the no detention policy for students up to eighth grade has helped to prevent children from being demotivated by their results (UNESCO 2012). However, this policy has also created a situation in which children may fail to learn basic skills (Taneja 2018). Thus, to shield students from the negative consequences of dropping out of school or repeating a grade, more attention should be paid to elementary schooling and the environments in which children spend most of their time. The present study has provided evidence on the association between different educational wellbeing indicators and the dropout and grade repetition rates among students (see Table A.2 in the appendix section). The analysis has shown the importance of these indicators in shaping the future of Indian students, and an awareness of these indicators can help policymakers to remove the barriers are leading some children to have negative educational outcomes. While various initiatives have helped to ensure that most younger Indian children are attending school, the high school dropout and grade repetition rates among secondary school students have led to questions being raised about the quality of the education children are being provided. Both the objective and subjective indicators 
of wellbeing presented in this study can be used by policymakers to improve the quality of the education Indian students are receiving.

In addition, our study found that school dropout and grade repetition rates were higher among children attending public school than they were among children attending private school. These results are consistent with those of an Indian study that found that public school students were more likely than private school students to drop out because of a shortage of effective public school teachers, and because the parents of public school students were less motivated to support their children's education (Desai et al. 2008b; Kundu 2019). In addition, our analysis showed that the children who did not receive private tuition and who were living in urban areas were more likely to drop out of school during adolescence. This evidence again points to the importance of effective and skilled school teachers, and of parents guiding their children in their lives and careers. It appears that when parents continuously motivate their children to do their best, and to excel in whatever activities they choose, their children have higher levels of achievement (Stegelin 2002). Moreover, it has been observed that rural area parents who are illiterate or did not get the chance to have an education themselves tend to be more enthusiastic about their children receiving an education, and that these positive attitudes have helped to improve the educational systems in rural areas. An Indian study has also identified different determinants that may play a role in the lower levels of education among children experiencing urban poverty (Singh 2013). In line with our findings, a study from rural India showed that children whose parents were illiterate had higher school dropout and grade retention rates (Drèze and Kingdon 2003). These results indicate that the involvement and encouragement of parents play important roles in the educational achievement of their children. Consistent with our findings, several studies have confirmed that a range of factors influence children's school performance, including the socio-economic conditions of the family, the quality of the school facilities, the level of support for learning in the home, and whether the child belongs to a Scheduled Caste or Tribe (Chauhan 2006; Gouda and Sekher 2014; Hunt 2008).

Our observation that the educational wellbeing of young children was associated with their future educational outcomes sheds light on significant shortcomings in India's educational system. With this study, we have sought to strengthen the educational literature for the Indian context by examining the factors associated with high rates of school dropout and grade repetition among secondary school students. Most of the past research on this topic focused on socio-economic conditions, parental characteristics, the school environment and household characteristics as the major determinants of educational outcomes. By contrast, this study is the first to show that children's school performance, learning skills, cognitive development, involvement in education and enjoyment of education during their elementary schooling affected their likelihood of dropping out of school or repeating a grade in secondary school. Much of the previous evidence on these associations was based on cross-sectional studies, which were able to capture only the immediate effects of the factors that may have contributed to the school dropout and grade repetition 
rates among children. However, by using a panel dataset, we were better able to capture the long-term consequences of educational wellbeing in young children.

Despite these advantages, our study also has some limitations. Our study was not able to establish any causal effects in the association between educational wellbeing and school dropout and grade repetition rates among students. Moreover, previous evidence has shown that the characteristics of the school children attend can affect their educational wellbeing, as their school is the only place other than their home where children routinely spend large amounts of time. Although a few factors related to school characteristics were provided in the study, a three-level random intercept model (in which individuals are nested within schools, which are, in turn, nested within states) would enable us to better control for the unobserved effects of the school environment.

\section{Conclusion}

The present study has provided conclusive evidence that low levels of both objective and subjective educational wellbeing while in elementary school can negatively affect children's longer-term prospects. It is worth noting that although the government of India had succeeded in encouraging younger children to attend school, many of these children are failing to acquire basic skills. Although India's educational policy is focused on the basic development of children, the educational wellbeing of elementary school children is often overlooked. Thus, the results of the current study indicate that policymakers should pay more attention to the experiences of elementary school students, as many of these children have low levels of educational wellbeing. We also recommend that the existing educational system be modernised to focus on the process of learning, rather than on educational outcomes only.

\section{Acknowledgements}

We would like to thank the two anonymous reviewers and the editors for their invaluable comments, which significantly improved this paper. This research did not receive any specific grant from funding agencies in the public, commercial or not-for-profit sectors.

\section{References}

Acock, A. C. 2013. Discovering structural equation modeling using Stata. College Station, TX: Stata Press Books.

Beauvais, F., E. L. Chavez, E. R. Oetting, J. L. Deffenbacher and G. R. Cornell 1996. Drug use, violence, and victimization among White American, Mexican American, 
and American Indian dropouts, students with academic problems, and students in good academic standing. Journal of Counseling Psychology 43(3): 292-299. https: //doi.org/10.1037/0022-0167.43.3.292

Bhat, P. N. M. and A. J. F. Zavier 2005. Role of religion in fertility decline: The case of Indian muslims. Economic and Political Weekly 40(5): 385-402.

Bornstein, M. H., L. Davidson, C. L. M. Keyes and K. A. Moore (eds) 2003. Well-being: Positive development across the life course. Psychology Press.

Cardoso, A. R. and D. Verner 2006. School drop-out and push-out factors in Brazil: The role of early parenthood, child labor, and poverty. IZA Discussion Paper 2515. Bonn: Institute for the Study of Labor (IZA).

Chauhan, C. 2006. SC/ST Dropout rates high. Hindustan Times. 22 October 2006.

Choudhury, A. 2006. Revisiting dropouts: Old issues, fresh perspectives. Economic and Political Weekly 41(51): 5257-5263.

Chudgar, A. 2009. The challenge of universal elementary education in rural India: Can adult literacy play a role? Comparative Education Review 53(3): 403-433. https://doi.org/10. $1086 / 599572$

Costello, A. B. and J. Osborne 2005. Best practices in exploratory factor analysis: Four recommendations for getting the most from your analysis. Practical Assessment, Research, and Evaluation 10(1): 7. https://doi.org/10.7275/jyj1-4868

Darling-Hammond, L., L. Flook, C. Cook-Harvey, B. Barron and D. Osher 2020. Implications for educational practice of the science of learning and development. Applied Developmental Science 24(2): 97-140. https://doi.org/10.1080/10888691.2018.1537791

Desai, S., A. Dubey, B. L. Joshi, M. Sen, A. Sharif and R. Vanneman. 2010. India human development survey users' guide release 03. University of Maryland and National Council of Applied Economic Research, New Delhi. https:/www.icpsr.umich.edu/web/pages/ DSDR/idhs-data-guide.html, accessed 23 December 2019.

Desai, S., A. Dubey and R. Vanneman 2015. India human development survey-II users' guide release 01. University of Maryland and National Council of Applied Economic Research, New Delhi. https://www.icpsr.umich.edu/web/pages/DSDR/idhs-II-data-guide. html, accessed 23 December 2019.

Desai, S. and R. Vanneman 2015. India human development survey-II (IHDS-II): 2011-12: Version 6. Inter-University Consortium for Political and Social Research. https://www. icpsr.umich.edu/web/DSDR/studies/36151/versions/V6, accessed 23 December 2019.

Desai, S., R. Vanneman and New Delhi National Council of Applied Economic Research. 2008a. India Human Development Survey (IHDS): 2005: Version 12. Inter-University Consortium for Political and Social Research. https://www.icpsr.umich.edu/web/DSDR/ studies/22626, accessed 23 December 2019.

Desai, S., A. Dubey, R. Vanneman and R. Banerji 2008b. Private schooling in India: A new educational landscape. Working Paper No. 11. India Human Development Survey.

Desai, U. 1991. Determinants of educational performance in India: Role of home and family. International Review of Education 37(2): 245-65. https://doi.org/10.1007/BF00599682

Dongre, A. A. and V. Tewary 2015. Impact of private tutoring on learning levels: Evidence from India. SSRN. https://doi.org/10.2139/ssrn.2401475 
Drèze, J. and G. G. Kingdon 2003. School participation in Rural India. Review of Development Economics 5(1): 1-24. https://doi.org/10.1111/1467-9361.00103

Ender, P. 2010. Collin: Stata command to compute collinearity diagnostics.

Fabrigar, L. R., D. T. Wegener, R. C. MacCallum and E. J. Strahan 1999. Evaluating the use of exploratory factor analysis in psychological research. Psychological Methods 4(3): 272. https://doi.org/10.1037/1082-989X.4.3.272

Falch, T. and B. Strøm 2008. Student progression in upper secondary education: The effect of academic ability, gender, and schools. Working Paper 9708, Trondheim: Department of Economics, Norwegian University of Science and Technology.

Fetler, M. 1989. School dropout rates, academic performance, size, and poverty: Correlates of educational reform. Educational Evaluation and Policy Analysis 11(2): 109-16. https: //doi.org/10.3102/01623737011002109

Filmer, D. and K. Scott 2008. Assessing asset indices. The World Bank.

Glick, P. and D. E. Sahn 2010. Early academic performance, grade repetition, and school attainment in Senegal: A panel data analysis. The World Bank Economic Review 24(1): 93-120. https://doi.org/10.1093/wber/lhp023

Gouda, J., K. Chandra Das, S. Goli and L. Maikho Apollo Pou 2013. Government versus private primary schools in India. International Journal of Sociology and Social Policy 3(11/12): 708-724. https://doi.org/10.1108/IJSSP-12-2012-0105

Gouda, S. M. and T. V. Sekher 2014. Factors leading to school dropouts in India: An analysis of National Family Health Survey-3 data. IOSR Journal of Research E Method in Education 4(6): 75-83. http://doi.org/10.9790/7388-04637583

Govinda, R. and M. Bandyopadhyay 2008. Access to elementary education in India. CREATE Country Analytic Review. Delhi/Brighton: NUEPA/University of Sussex.

Haidary, A. 2013. Controvercy over grade repetition: Afghan teachers' view on grade repetition. Thesis, Karlstad University.

Hunt, F. M. 2008. Dropping out from school: A cross country review of literature. CREATE Pathways to Access, Research Monographs No. 16. Delhi/Brighton: NUEPA/University of Sussex.

Jimerson, S. R. 2001. Meta-analysis of grade retention research: Implications for practice in the 21st century. School Psychology Review 30(3): 420-437. https://doi.org/10.1080/ 02796015.2001.12086124

Kline, P. 2000. Reliability of tests: Practical issues. In Handbook of psychological testing, ed P. Kline, 7-17. Second Edition. London: Routledge.

Kundu, P. 2019. Deteriorating quality of education in schools: Are teachers responsible? Economic and Political Weekly. Economic E Political Weekly 54(24).

Lloyd, C. B., C. Mete and M. J. Grant 2009. The implications of changing educational and family circumstances for children's grade progression in rural Pakistan: 1997-2004. Economics of Education Review 28(1): 152-160. https://doi.org/10.1016/j.econedurev. 2007.04.005

Marphatia, A. A., A. M. Reid and C. S. Yajnik 2019. Developmental origins of secondary school dropout in rural India and its differential consequences by sex: A biosocial life course analysis. International Journal of Educational Development 66: 8-23. https: //doi.org/10.1016/j.ijedudev.2018.12.001 
McGrath, H. 2006. To repeat, or not to repeat. Words 26(2): 39-46.

Merlo, J., B. Chaix, H. Ohlsson, A. Beckman, K. Johnell, P. Hjerpe, L. Råstam and K. Larsen 2006. A brief conceptual tutorial of multilevel analysis in social epidemiology: Using measures of clustering in multilevel logistic regression to investigate contextual phenomena. Journal of Epidemiology $\mathcal{E}$ Community Health 60(4): 290-297.

MHRD. 2020. National education policy 2020. Government of India.

Muttarak, R. and T. Chankrajang 2015. Who is concerned about and takes action on climate change? Gender and education divides among Thais. Vienna Yearbook of Population Research 13: 193-220. https://doi.org/10.1553/populationyearbook2015s193

OECD 2003. Financing education: Investments and returns: Analysis of the world education indicators. vol. 3. OECD Publishing.

Paul, R., R. Rashmi and S. Srivastava 2021. Does lack of parental involvement affect school dropout among Indian adolescents? Evidence from a panel study. PLOS ONE 16(5): e0251520. https://doi.org/10.1371/journal.pone.0251520

Pong, S.-L. and D.-B. Ju 2000. The effects of change in family structure and income on dropping out of middle and high school. Journal of Family Issues 21(2): 147-169. https://doi.org/10.1177/019251300021002001

Pratinidhi, A. K., S. V. Warerkar and S. G. Garad 1992. A study of school dropouts in an urban slum community. Demography India 21(2): 301-305.

Rao, M. J. M. 2000. Migration of labour and school dropouts. Social Welfare-Delhi 47(6): 26-31.

Rutstein, S. O. and K. Johnson 2004. The DHS Wealth Index. DHS Comparative Reports No. 6. Calverton: ORC Macro.

Sabates, R., J. Westbrook, K. Akyeampong and F. Hunt. 2010. School drop out: Patterns, causes, changes and policies. issues. background paper for the education for all global monitoring report 2011, The hidden crisis: Armed conflict and education. UNESCO.

Sanjay, A. 2020. The creation and mobilization of anti-China sentiment by interest groups in Indian society (2012-2018). CURA Paper No. 1. Qatar: Center for International and Regional Studies. Georgetown University in Qatar.

Sethi, I. K. 2018. Parental aspirations and educational outcomes: Evidence from Andhra Pradesh, India. Thesis, University of Oxford.

Singh, B. G. 2013. A study of the reasons of urban deprived children repeatedly becoming out-of-school even after their mainstreaming in the regular schooling system. Research Report. School of Studies in Psychology. Pt. Ravishankar Shukla University.

Singh, R., R. Kesarwani and P. Mukherjee 2019. Exploring well-being among 22-yearold youth in India. Working Paper 184. Oxford: Young Lives, Oxford Department of International Development (ODID): University of Oxford.

Singhal, K. and U. Das 2019. Revisiting the role of private schooling on children learning outcomes: Evidence from rural India. South Asia Economic Journal 20(2): 274-302. https://doi.org/10.1177/1391561419853678

StataCorp, L. P. 2014. Stata 14. College Station, TX: StataCorp LP.

Steele, F. 2013. Module 10: Single-level and multilevel models for nominal responses: MLwiN Practical. Centre for Multilevel Modelling. 
Stegelin, D. A. 2002. Early literacy education: First steps toward dropout prevention. Effective strategies for school improvement and dropout prevention. Clemson, SC: National Dropout Prevention Center.

Sylva, K. 1994. School influences on children's development. Journal of Child Psychology and Psychiatry 35(1): 135-70. https://doi.org/10.1111/j.1469-7610.1994.tb01135.x

Taneja, A. 2018. No detention under the RTE Act: The policy options. Education Policy Brief New Delhi: CARE India.

UNESCO. 2012. Global education digest 2012. Opportunities lost: The impact of grade repetition and early school leaving. UNESCO Institute for Statistics Quebec.

Upendranath, C. 1995. Education of girls in India: The daunting task ahead. Journal of Educational Planning and Administration 9: 81-92.

Wat, A. 2015. Transforming the workforce for children birth through age 8: A unifying foundation. Washington, DC: The National Academies Press. https://doi.org/10.17226/ 19401

\section{Appendix}

Table A.1:

Distribution of students by variables used for preparing the educational wellbeing index

\begin{tabular}{lrr}
\hline Characteristics & $\boldsymbol{N}$ & \% \\
\hline Type of student & & \\
Below average & 982 & 10.0 \\
Average & 7,645 & 77.8 \\
Above average & 1,195 & 12.2 \\
Student enjoys school & & \\
No & 525 & 5.3 \\
Yes & 9,297 & 94.7 \\
Reading skills & & \\
Cannot read letters & 592 & 6.0 \\
Can read alphabets & 932 & 9.5 \\
Can read words & 1,467 & 14.9 \\
Can read a short paragraph & 4,066 & 41.4 \\
Can read a full story & 2,765 & 28.2 \\
Mathematical skills & & 11.8 \\
Cannot recognise numbers & 1,159 & 23.7 \\
Can recognise numbers & 2,326 & 46.4 \\
Can do subtraction & 4,558 & 18.1 \\
Can do division & 1,779 & \\
Writing skills & & 22.0 \\
Cannot write & 2,161 & 78.0 \\
Can write & 7,661 & $\mathbf{1 0 0}$ \\
Overall & $\mathbf{9 , 8 2 2}$ & \\
\hline
\end{tabular}


Table A.2:

Odds ratios from the random-intercept logistic regression models showing the association of the indicators of educational wellbeing in round one with the school dropout and grade repetition status of students in round two

\begin{tabular}{|c|c|c|c|c|}
\hline \multirow[b]{3}{*}{ Characteristics } & \multicolumn{4}{|c|}{ Students aged 15-18 years in 2012} \\
\hline & \multicolumn{2}{|c|}{ School dropout } & \multicolumn{2}{|c|}{ Grade repetition } \\
\hline & OR & $95 \% \mathrm{CI}$ & OR & $95 \% \mathrm{CI}$ \\
\hline \multicolumn{5}{|l|}{ Type of student } \\
\hline \multicolumn{5}{|l|}{ Above average ${ }^{\circledR}$} \\
\hline Average & 1.19 & $(0.98-1.44)$ & 1.11 & $(0.91-1.34)$ \\
\hline Below average & $1.54^{*}$ & $(1.21-1.97)$ & 1.26 & $(0.98-1.62)$ \\
\hline \multicolumn{5}{|l|}{ Student enjoys school } \\
\hline \multicolumn{5}{|l|}{ Yes $^{\circledR}$} \\
\hline No & 1.06 & $(0.85-1.32)$ & 1.08 & $(0.85-1.37)$ \\
\hline \multicolumn{5}{|l|}{ Reading skills } \\
\hline \multicolumn{5}{|l|}{ Can read story ${ }^{\circledR}$} \\
\hline Can read a paragraph & $1.34^{*}$ & $(1.14-1.58)$ & 1.06 & $(0.90-1.24)$ \\
\hline Can read words & $1.29^{*}$ & $(1.05-1.59)$ & 1.13 & $(0.91-1.40)$ \\
\hline Can read alphabets & $1.73^{*}$ & $(1.36-2.19)$ & 1.06 & $(0.82-1.37)$ \\
\hline Cannot read letters & $1.48^{*}$ & $(1.10-1.99)$ & $0.68^{*}$ & $(0.48-0.96)$ \\
\hline \multicolumn{5}{|l|}{ Mathematical skills } \\
\hline \multicolumn{5}{|l|}{ Can do division ${ }^{\circledR}$} \\
\hline Can do subtraction & 1.17 & $(0.96-1.44)$ & $1.32^{*}$ & $(1.09-1.61)$ \\
\hline Can recognise numbers & $1.49^{*}$ & $(1.19-1.87)$ & $1.31^{*}$ & $(1.04-1.64)$ \\
\hline Cannot recognise numbers & $1.44^{*}$ & $(1.08-1.90)$ & $1.44^{*}$ & $(1.07-1.92)$ \\
\hline \multicolumn{5}{|l|}{ Writing skills } \\
\hline \multicolumn{5}{|l|}{ Can write ${ }^{\mathbb{B}}$} \\
\hline Cannot write & 1.08 & $(0.92-1.27)$ & $1.28^{*}$ & $(1.08-1.53)$ \\
\hline \multicolumn{5}{|l|}{ Age of student (in years) } \\
\hline \multicolumn{5}{|l|}{$8^{\mathbb{Q}}$} \\
\hline 9 & $1.48^{*}$ & $(1.25-1.74)$ & $1.24^{*}$ & $(1.04-1.48)$ \\
\hline 10 & $2.17^{*}$ & $(1.87-2.52)$ & $1.59^{*}$ & $(1.36-1.86)$ \\
\hline 11 & $2.89^{*}$ & $(2.44-3.44)$ & $1.86^{*}$ & $(1.56-2.23)$ \\
\hline \multicolumn{5}{|l|}{ Gender of student } \\
\hline \multicolumn{5}{|l|}{ Male $^{\circledR}$} \\
\hline Female & 1.06 & $(0.95-1.17)$ & $0.82^{*}$ & $(0.73-0.92)$ \\
\hline \multicolumn{5}{|c|}{ Type of school attended by student } \\
\hline \multicolumn{5}{|c|}{ Private school ${ }^{\circledR}$} \\
\hline Public school & $1.70^{*}$ & $(1.42-2.02)$ & $1.42^{*}$ & $(1.19-1.68)$ \\
\hline Others & $1.58^{*}$ & $(1.18-2.12)$ & $1.42^{*}$ & $(1.06-1.91)$ \\
\hline
\end{tabular}

Continued 
Table A.2:

Continued

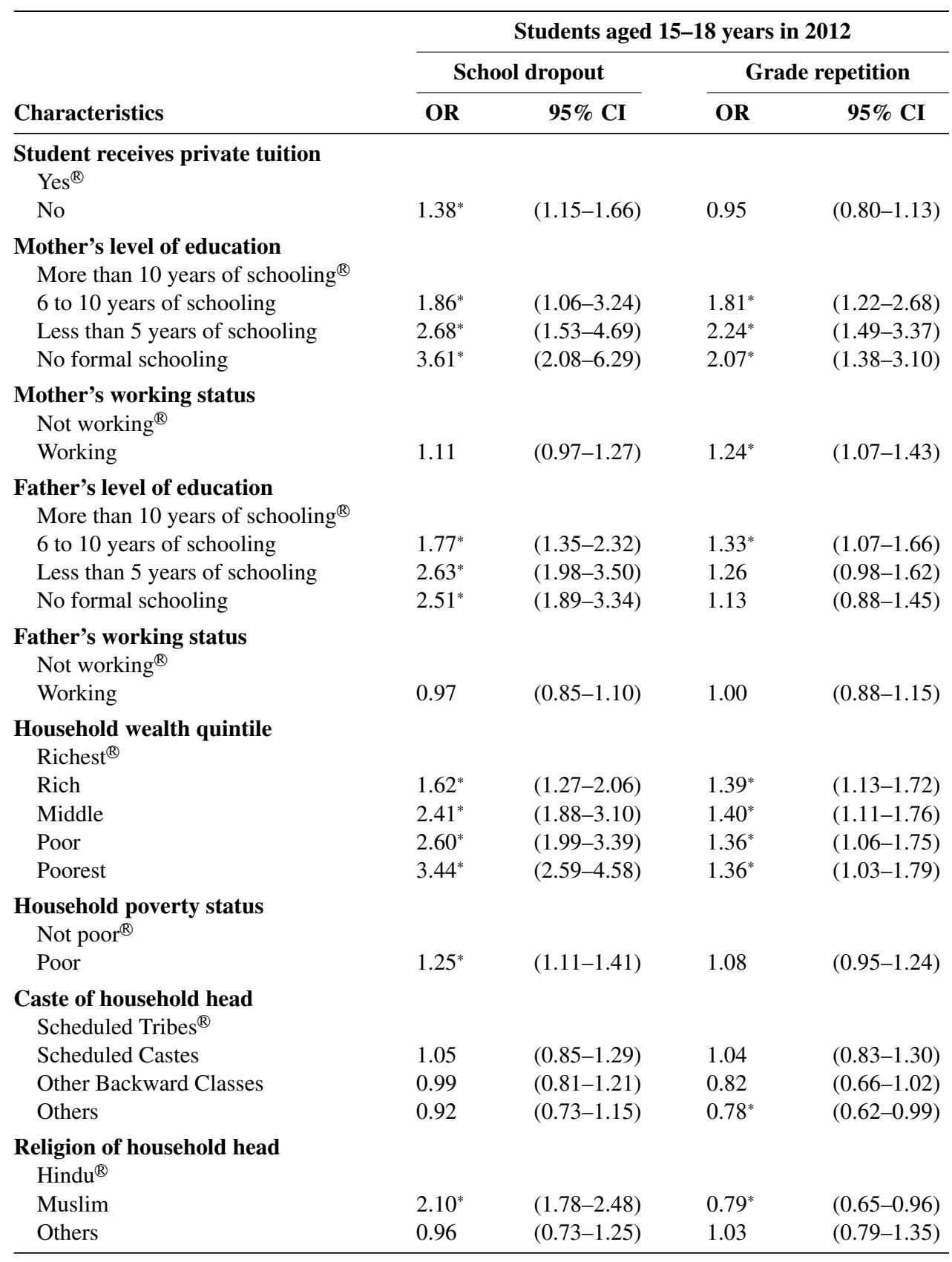

Continued 
Table A.2:

Continued

Students aged 15-18 years in 2012

\begin{tabular}{|c|c|c|c|c|}
\hline & & & & \\
\hline \multirow[b]{2}{*}{ Characteristics } & \multicolumn{2}{|c|}{ School dropout } & \multicolumn{2}{|c|}{ Grade repetition } \\
\hline & OR & $95 \% \mathrm{CI}$ & OR & $95 \% \mathrm{CI}$ \\
\hline \multicolumn{4}{|l|}{ Place of residence } & Rural $^{\mathbb{B}}$ \\
\hline Urban & $1.45^{*}$ & $(1.25-1.69)$ & 1.10 & $(0.94-1.28)$ \\
\hline \multicolumn{4}{|l|}{ Country regions } & \\
\hline North-eastern & 1.74 & $(0.59-5.13)$ & 0.69 & $(0.27-1.73)$ \\
\hline Central & 1.30 & $(0.59-2.87)$ & 1.70 & $(0.88-3.26)$ \\
\hline Eastern & 1.03 & $(0.55-1.91)$ & 0.65 & $(0.38-1.11)$ \\
\hline Western & $2.95^{*}$ & $(1.54-5.67)$ & $0.46^{*}$ & $(0.25-0.84)$ \\
\hline Southern & 1.02 & $(0.56-1.84)$ & $0.50^{*}$ & $(0.31-0.82)$ \\
\hline Number of states & \multicolumn{2}{|c|}{21} & \multicolumn{2}{|c|}{21} \\
\hline Number of students & \multicolumn{2}{|c|}{$\mathbf{9 , 8 2 2}$} & \multicolumn{2}{|c|}{$\mathbf{9 , 8 2 2}$} \\
\hline
\end{tabular}

Note: (a) OR stands for the odds ratio. (b) The 95\% confidence interval (CI) is given in brackets. (c) Statistical significance is denoted by asterisks where $*$ denotes p-value $<0.05$. (d) ${ }^{\circledR}$ denotes the reference category. (e) School dropout and grade repetition variable categorised into no, yes. 


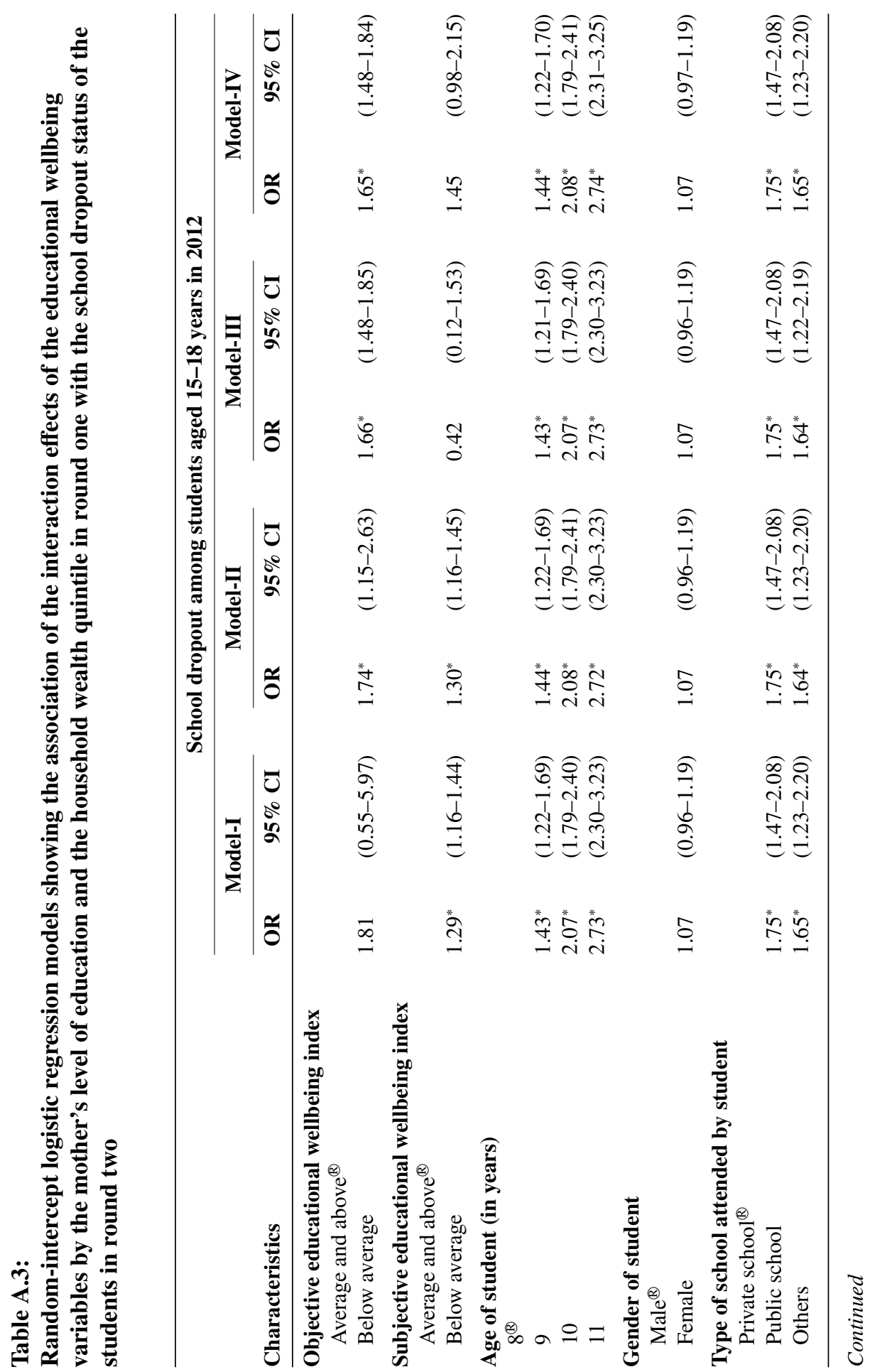




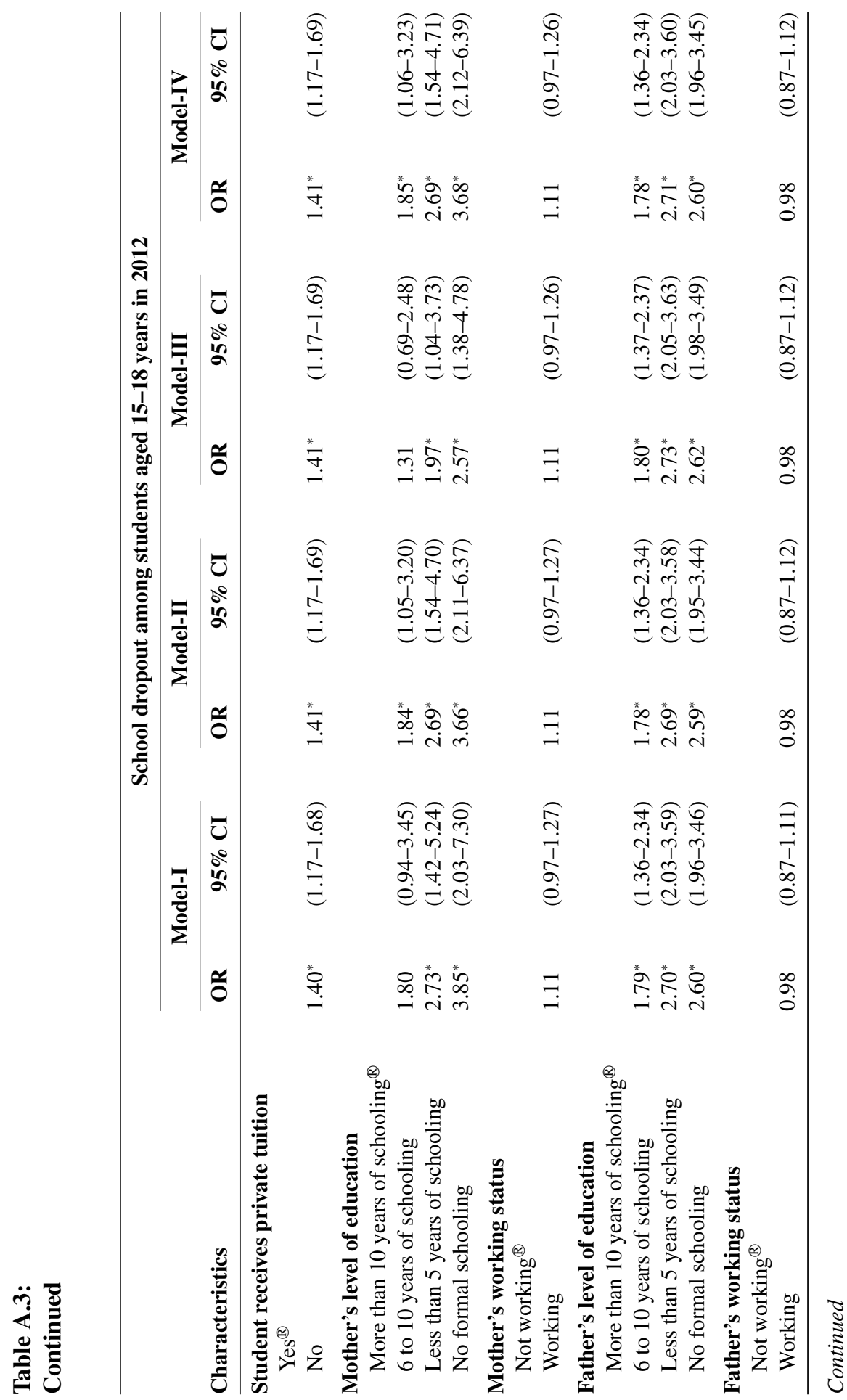




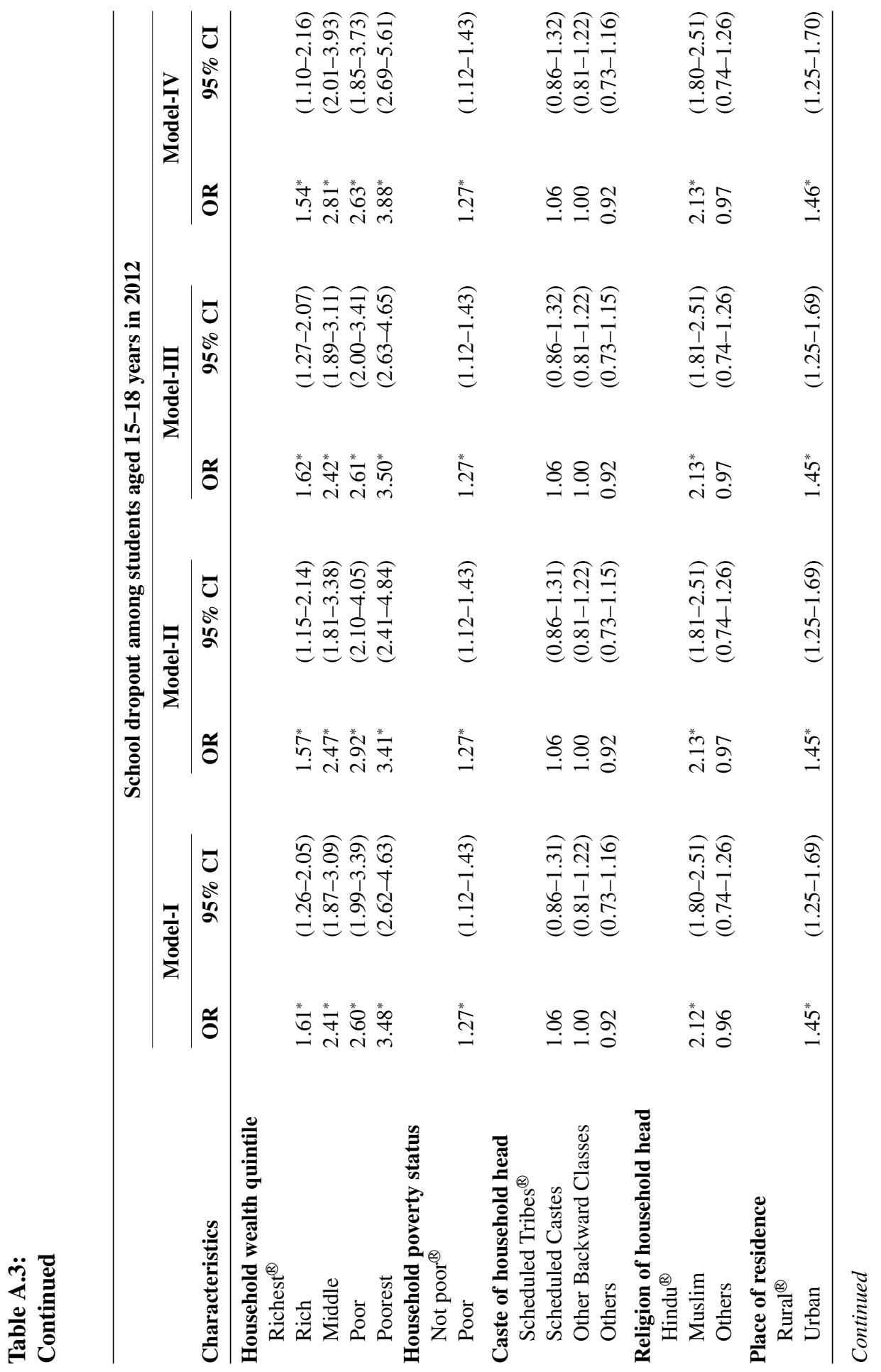




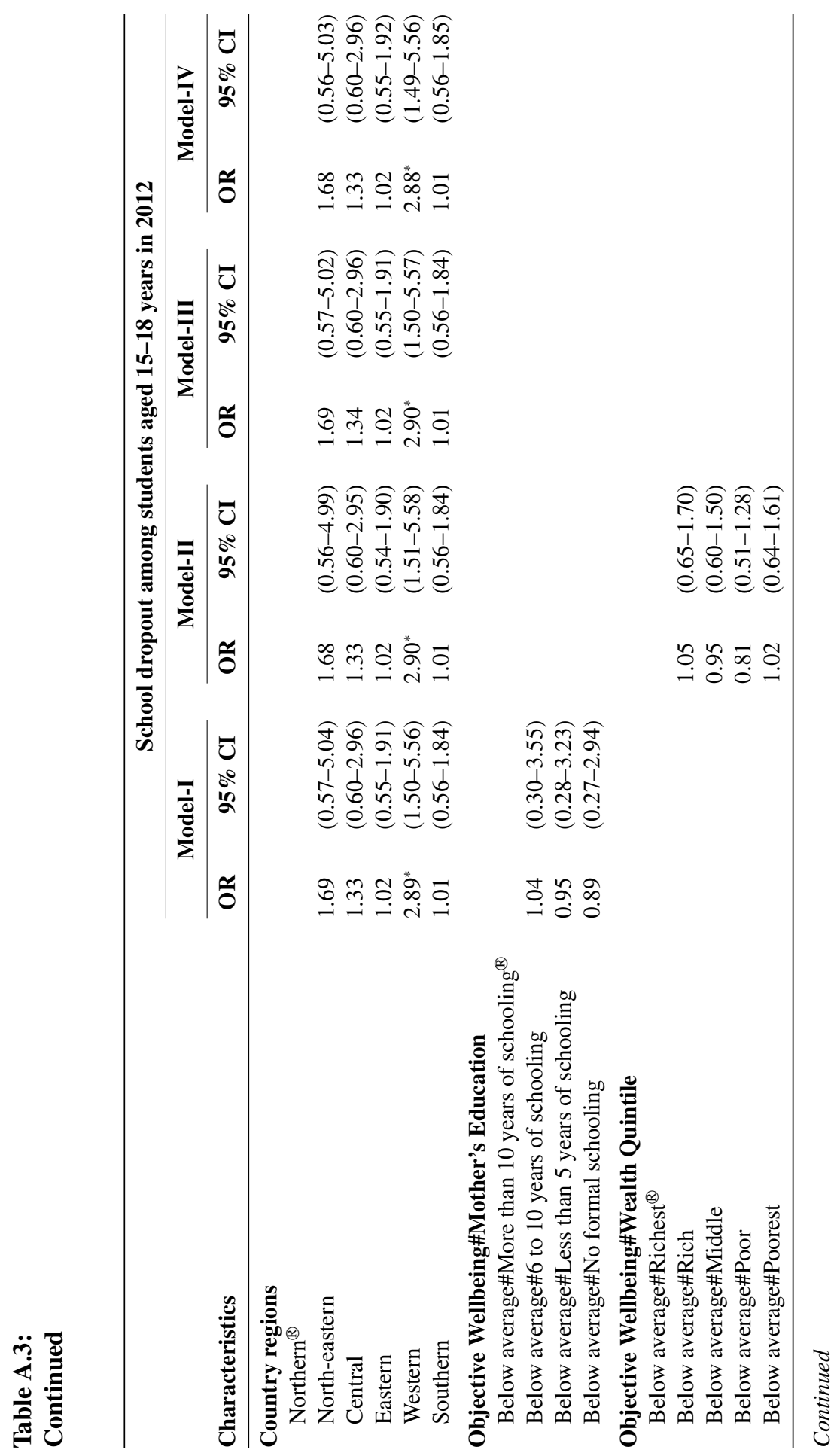




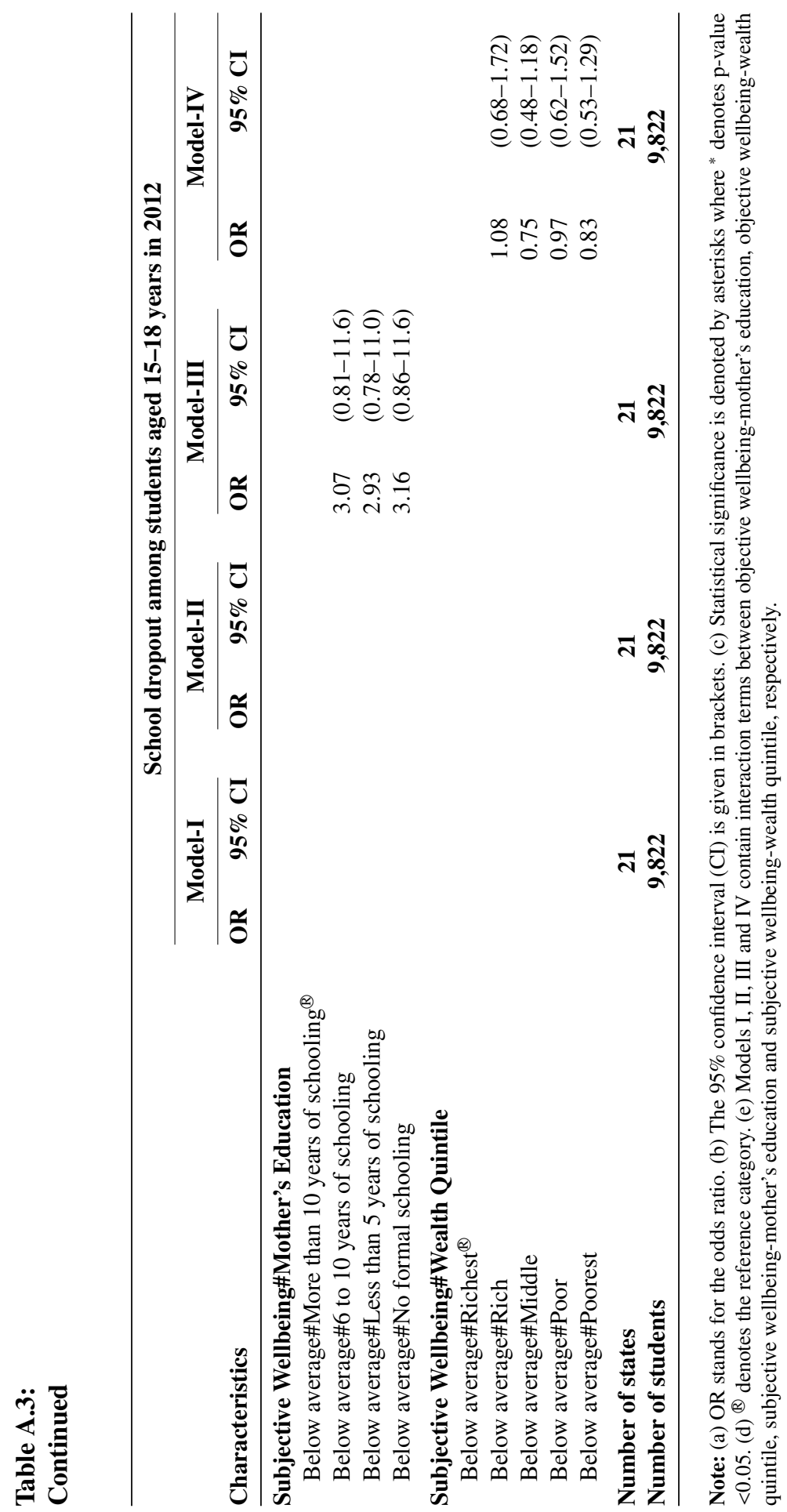




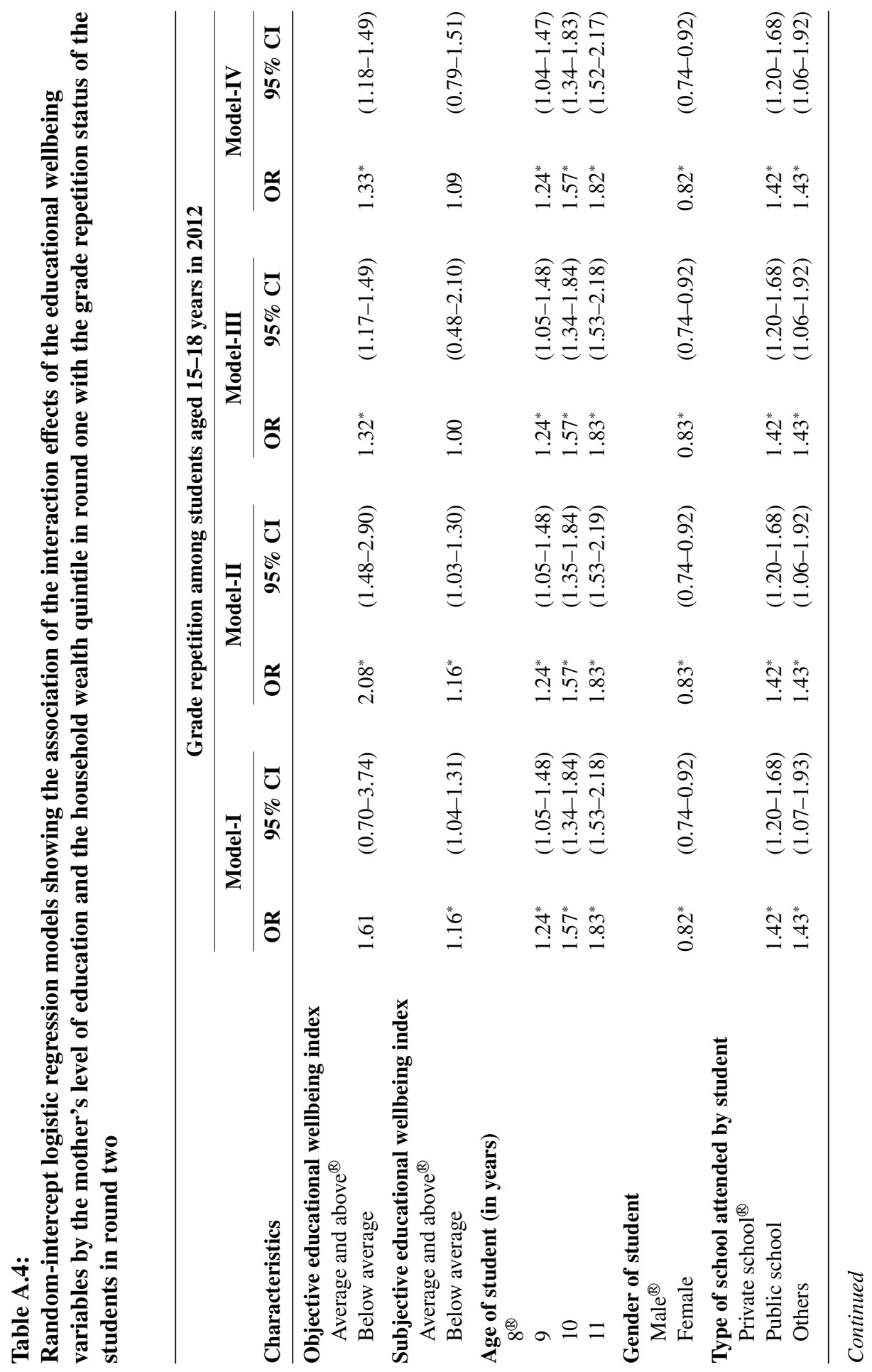




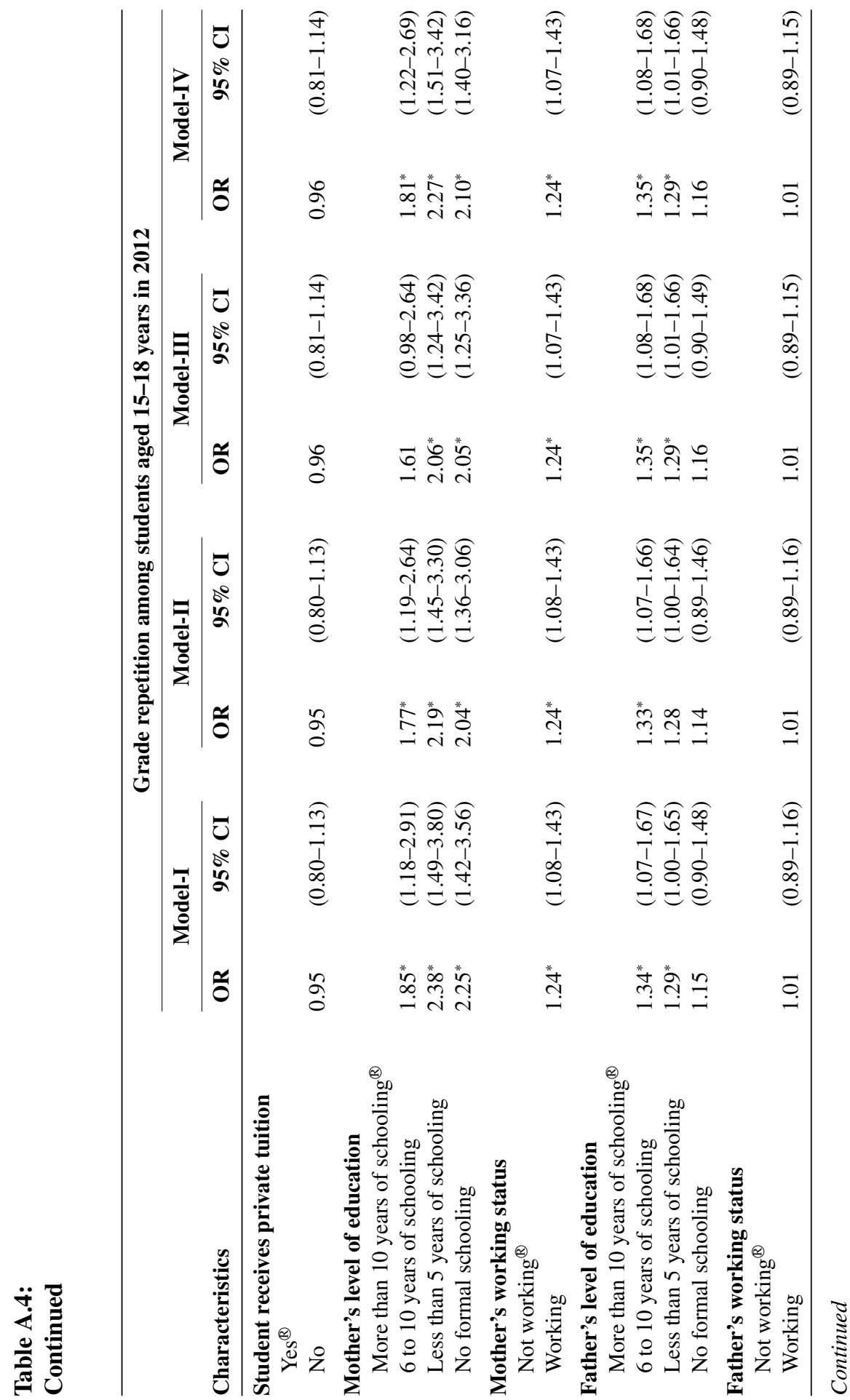




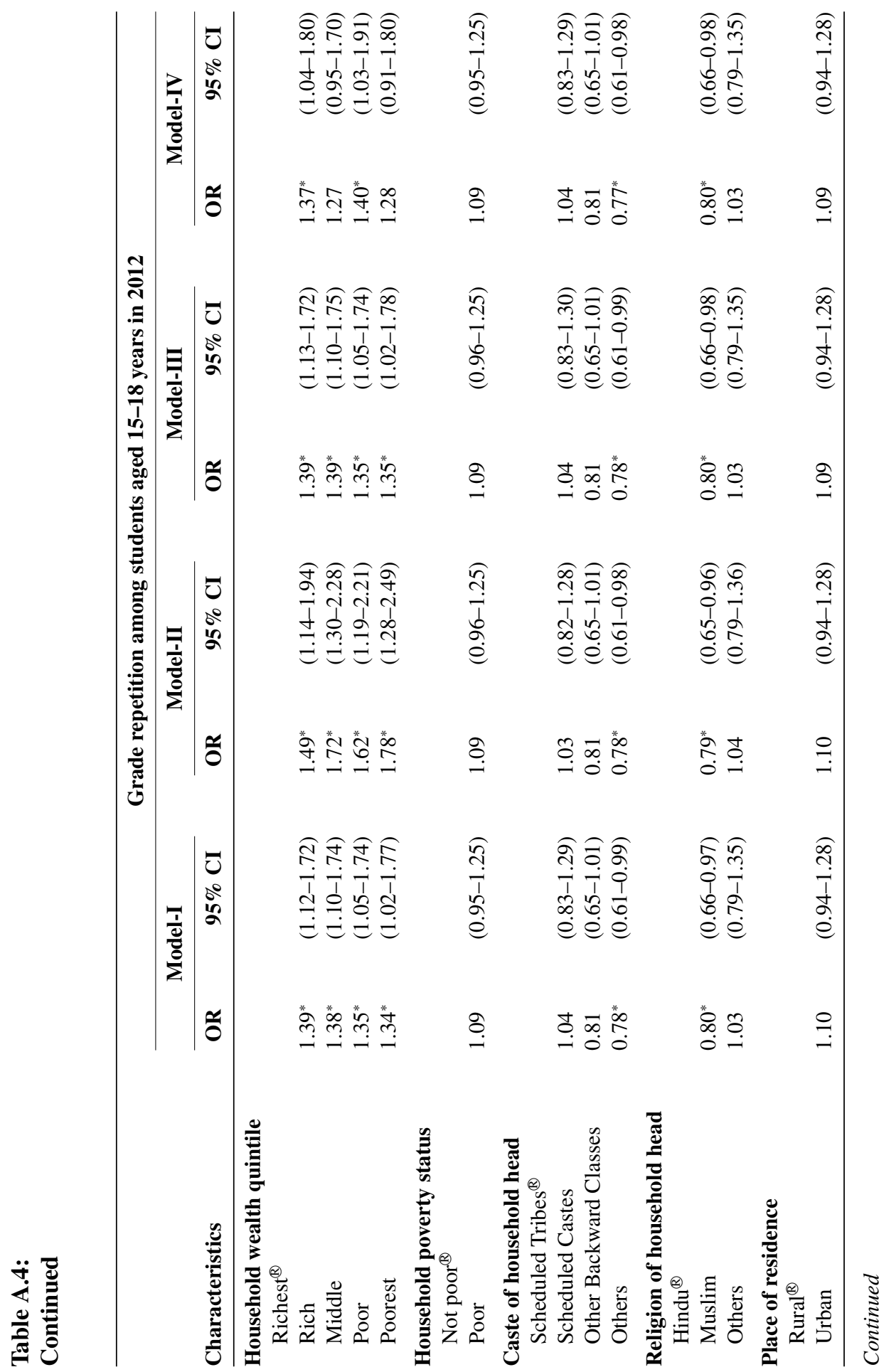




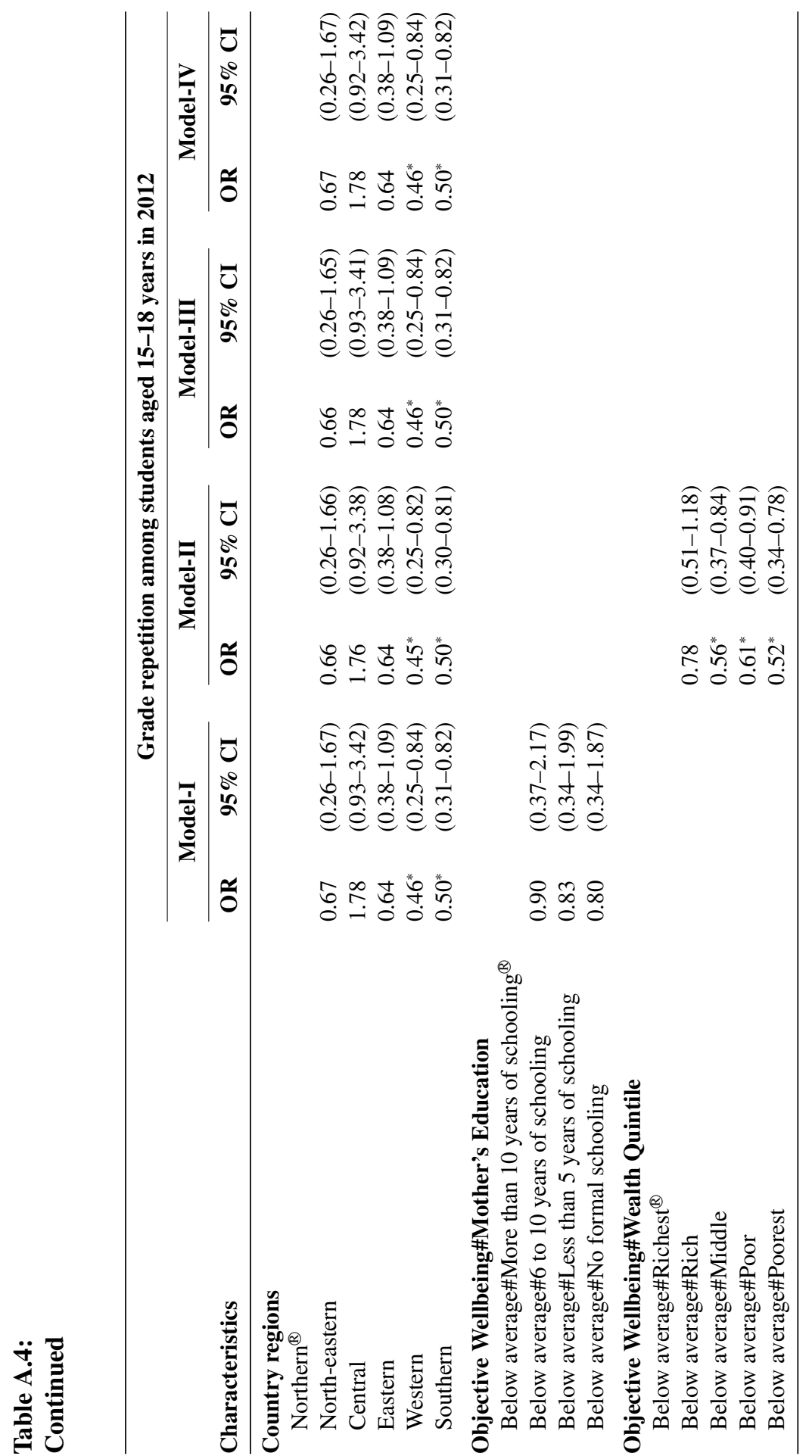




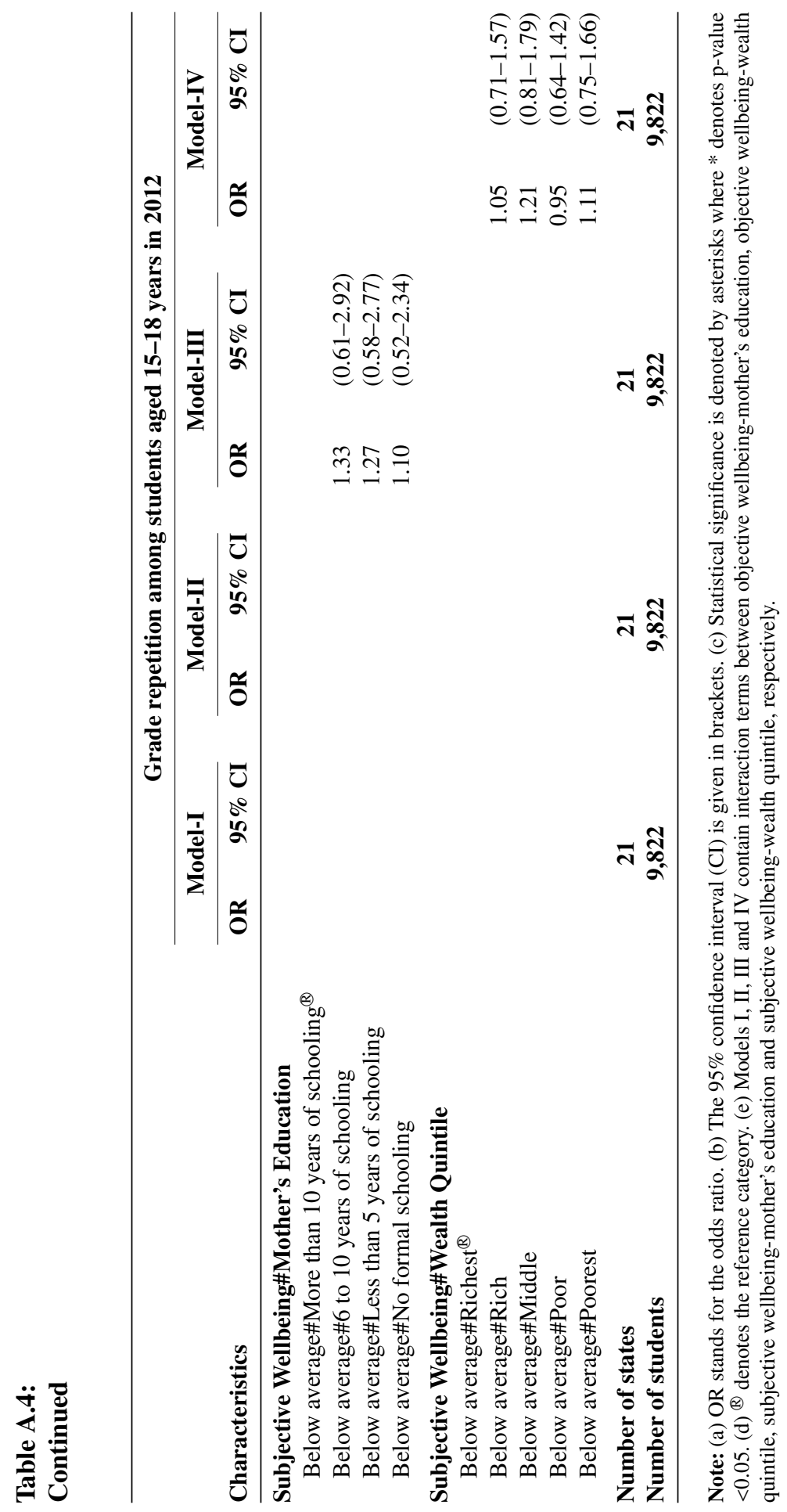


Open Access This article is published under the terms of the Creative Commons Attribution 4.0 International License (https://creativecommons.org/licenses/by/4.0/) that allows the sharing, use and adaptation in any medium, provided that the user gives appropriate credit, provides a link to the license, and indicates if changes were made. 